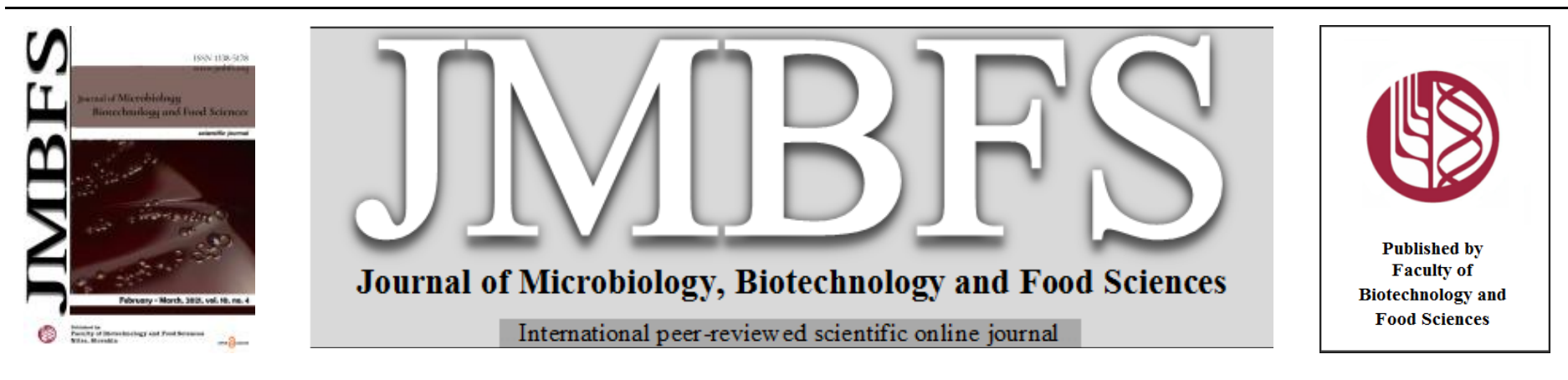

\title{
CAMPYLOBACTER AS A MAJOR FOODBORNE PATHOGEN: A REVIEW OF ITS CHARACTERISTICS, PATHOGENESIS, ANTIMICROBIAL RESISTANCE AND CONTROL
}

\author{
Ahmed M. Ammar ${ }^{1}$, El-Sayed Y. El-Naenaeey ${ }^{1}$,Marwa I. Abd El-Hamid ${ }^{1}$,Attia A. El-Gedawy ${ }^{2}$ and Rania M. S. El-Malt ${ }^{* 3}$ \\ Address(es): Rania Mohamed Saied El-Malt, \\ ${ }^{1}$ Zagazig University, Faculty of Veterinary Medicine, Department of Microbiology, $19^{\text {th }}$ Saleh Abo Rahil Street, El-Nahal, 44519, Zagazig, Sharkia, Egypt. \\ ${ }^{2}$ Animal health Research Institute, Department of Bacteriology, Tuberculosis unit, Nadi El-Seid Street,12618 Dokki, Giza, Egypt. \\ ${ }^{3}$ Animal health Research Institute, Department of Microbiology, El-Mohafza Street, 44516, Zagazig, Sharkia, Egypt, +201061463064.
}

*Corresponding author: Raniaelmalt@yahoo.com

doi: 10.15414/jmbfs.2021.10.4.609-619

ARTICLE INFO

Received 7. 2. 2020

Revised 2. 10. 2020

Accepted 27. 10. 2020

Published 1. 2. 2021

$\overline{\text { Review }}$

\begin{abstract}
Campylobacter, mainly Campylobacter jejuni is viewed as one of the most well-known reasons of foodborne bacterial diarrheal sickness in people around the globe. The genus Campylobacter contains 39 species (spp.) and 16 sub spp. Campylobacter is microaerophilic, Gram negative, spiral-shaped rod with characteristic cork screw motility. It is colonizing the digestive system of numerous wild and household animals and birds, particularly chickens. Intestinal colonization brings about transporter/carrier healthy animals. Consequently, the utilization of contaminated meat, especially chicken meat is the primary source of campylobacteriosis in humans and chickens are responsible for an expected $80 \%$ of human campylobacter infection. Interestingly, in contrast with the most recent published reviews that cover specific aspects of campylobacter/campylobacteriosis, this review targets the taxonomy, biological characteristics, identification and habitat of Campylobacter spp. Moreover, it discusses the pathogenesis, resistance to antimicrobial agents and public health significance of Campylobacter spp. Finally, it focuses on the phytochemicals as intervention strategies used to reduce Campylobacter spp.in poultry production.
\end{abstract}

Keywords: Campylobacter, Campylobacter jejuni, foodborne, campylobacteriosis, poultry, phytochemicals, virulence

\section{INTRODUCTION}

Attention to the public health significance of Campylobacter infection has advanced over a century. Campylobacteriosis of extraordinary general wellbeing significance is Campylobacter enteritis caused mainly by Campylobacter jejuni (C. jejuni) and Campylobacter coli (C. coli), but to a lesser extent (Goni et al. 2017 and García-Sánchez et al. 2018). C. jejuni has become the most common recognized reason of foodborne bacterial gastroenteritis in people in developed countries (EFSA-ECDC, 2009; CDC, 2014 and Whitehouse et al. 2018).

Campylobacteriosis is a self-limited disease and antimicrobial treatment is not indicated for the most part. Notwithstanding, under explicit clinical conditions, anti-microbial treatment might be fundamental, but treatment might be convoluted because the development of antimicrobial resistant Campylobacter strains as a result of the common utilization of antimicrobial agents in agriculture and veterinary medicine (Bhunia, 2018 and Silva et al. 2018a).

For the consumer's safety, it is important to characterize the pathogenicity markers in strains that are recognized in food. C. jejuni has a few putative virulence genes, which have perceived to be liable for the pathogenicity expression (Bolton, 2015 and García-Sánchez et al. 2018).

Genotyping of Campylobacter spp. has been developed for studying the genetic variety and the link between the isolates from various origins to control human or animal health problems (Malakauskas et al. 2017).

Chickens are recognized as the primary reservoir of thermotolerant Campylobacter spp. and they are the main source of human campylobacter infection. Therefore, intervention procedures for controlling Campylobacter in chickens have been created to diminish product contamination and subsequently the rate of Campylobacter diseases in human (Upadhyay et al. 2019). With expanding the consumer requests for safe and natural products with negligible preservatives, important researches are being conducted to investigate the capability of natural antimicrobials for example, phytochemicals for controlling C. jejuni in chickens (Wagle $\boldsymbol{e t}$ al. 2017a and Wagle $\boldsymbol{e t}$ al. 2019). Thus, this review shed light on all important issues related to Campylobacter spp. including (i) the history, taxonomy and biological characteristics (ii) isolation, identification and natural habitat (iii) pathogenesis, virulence factors and resistance to antimicrobial agents and (iv) public health significance of
Campylobacter spp. and (v) phytochemicals as intervention strategies used to reduce Campylobacter in poultry production.

\section{HISTORICAL EMERGENCE OF CAMPYLOBACTER SPECIES}

The genus Campylobacter comprises a huge and various group of bacteria. In 1886, Campylobacter was primary documented by Theodor Escherich which stated the appearance of nonculturable helical-shaped bacteria in smears of the mucosa of the large intestine related with diarrhea in children deceased of what he called "Cholera infantum". The primary isolation of campylobacters (a vibriolike bacterium) was made from the uterus of aborted sheep in 1906 (Kist, 1986). In 1912, a similar pathogen was isolated from fetus of aborted cow and called Vibrio fetus (Smith and Taylor, 1919). Fifteen years later, another vibrio pathogen was found in faeces of cattle suffering from diarrhea and later called Vibrio jejuni (Jones et al. 1931). In 1944, Vibrio coli was isolated from diarrheic pigs (Doyle, 1948).

Campylobacter was considered as a cause of animal illness for over 40 years, except only in 1938 when Campylobacter spp. were incriminated in foodborne disease outbreak. A Vibrio jejuni like pathogen was detected in the blood of 13 victims of an outbreak due to the ingestion of contaminated milk and this outbreak caused acute diarrheal illness in 357 inmates in Illinois state institutions in the United States (Levy, 1946).

In 1963, due to their specific characteristics for example low DNA base composition (low $\mathrm{G}+\mathrm{C}$ content), microaerophilic development and nonfermentative metabolism, these microorganisms were moved into the recently made genus Campylobacter to recognize these bacteria from the Vibrio spp. (Sebald and Veron, 1963 and Silva et al. 2011). The genus's name means bended/ curved which derived from the Greek expression "kampyo's" (Keener $\boldsymbol{e t}$ al. 2004 and Silva et al. 2018a).

The first proper description of the genus Campylobacter was given by the American bacteriologist Elisabeth King, which was committed to find the proper techniques to isolate these bacteria from faeces because she believed that the prevalence of Campylobacter was more than the few reported cases (Butzler, 2004 and García-Sánchez et al. 2018).

In the early 1970s, a special filtration method was developed for identification of Campylobacter in veterinary medicine, which allowed Butzler to detect these 
bacteria from stools of human patients suffering from high body temperature and diarrhea (Butzler et al. 1973). But, the primary advance toward the isolation of Campylobacter was accomplished by incorporation of specific antimicrobial agents to the basal media including trimethoprim, polymyxin B and vancomycin (Skirrow, 1977).

In 1973, a detailed research on the microaerophilic vibrio-like organism's taxonomy was done by Veron and Chatelain and they found that the genus Campylobacter had 4 separate spp. including C. coli, C. sputorum, C. fetus and C. jejuni (Veron and Chatelain, 1973).

Just during the 1980 s, about 100 years subsequent to its primary detection, $C$ jejuni was recognized as one of the most well-known reasons of foodborne bacterial enteritis in human worldwide (García-Sánchez et al. 2018).

\section{NOMENCLATURE AND CLASSIFICATION OF CAMPYLOBACTER SPECIES}

The genus Campylobacter has a place within the phylum Proteobacteria, the class Epsilonproteobacteria, the order Campylobacterales and the family Campylobacteraceae. The genus Campylobacter taxonomy is in continues variation from its origin because of the re-classification of certain spp. into different genera or the discovery of new spp. (Silva et al. 2018a).

As of now, the genus Campylobacter contains at least 39 spp. and 16 sub spp. with valid published names (http://www.bacterio.net/campylobacter.html accessed 08 August 2019). Twelve spp. of the genus Campylobacter are viewed as pathogenic bacteria such as $C$. lari, $C$. curvus, $C$. coli, $C$. concisus, $C$. fetus, $C$. upsaliensis and C. jejuni. Disease caused by Campylobacter might cause gastroenteritis; but, $C$. jejuni has additionally been incriminated in systemic infections (Bhunia, 2018)

C. coli and C. jejuni subspp. jejuni are commonly related to human campylobacteriosis representing up to $90 \%$ of the outbreaks and sporadic campylobacteriosis cases (Debruyne et al. 2008; Llarena, 2015 and Llarena et al. 2015).

Additionally, $C$. jejuni consists of 2 sub spp.; $C$. jejuni subsp Doylei and $C$. jejuni subsp jejuni. However, the $C$. jejuni subsp doylei pathogenic role is unknown yet, but it was detected in blood samples of infected children (Llarena, 2015 and Llarena et al. 2015). These two sub spp. varies biochemically and they can be differentiated by polymerase chain reactions (PCR) on the basis of the nitrate reductase (nap) locus (napA and napB genes), where C. jejuni subsp Doylei strains contained napA deletions of 2761 bp (Miller et al. 2007 and GarcíaSánchez et al. 2018). C. jejuni sub spp. jejuni will hereafter be referred to as C. jejuni.

A system for typing Campylobacter spp. depending on the heat-stable lipopolysaccharide (LPS) O-antigenic components has differentiated C. coli, C. lari and C. jejuni into 60 serotypes, although another typing system dependent on heat-labile antigen has detected 100 serotypes of these bacteria (Bhunia, 2018). Moreover, Miller and Parker reported that C. lari, C. upsaliensis, C. jejuni and $C$. coli are related genetically and are referred to as the thermotolerant campylobacters, due to their growth at $42^{\circ} \mathrm{C}$. These four Campylobacter spp. considered the principle spp. of public health and clinical significance. The remaining spp. of the genus Campylobacter form 3 general groups: (1) spp. that have not been associated with human disease and are not detected in water or food (eg, C. canadensis and C. insulaenigrae) (2) spp. that have been incriminated with children and human diseases (eg, C. showae, $C$. rectus, $C$ curvus and $C$. concisus) and (3) spp. that have been associated with disease in livestock animals and infrequently causes human illness (e.g. C. sputorum, $C$. fetus and C. hyointestinalis) (Miller and Parker, 2011 and Fitzgerald, 2015). Among the genus Campylobacter, C. iguaniorum, C. corcagiensis, C. troglodytis, C. volucris, $C$. avium, $C$. canadenses, $C$. subantarcticus and $C$. cuniculorum are the only spp. that didn't cause animals or human diseases yet (Fitzgerald, 2015).

\section{MOLECULAR TAXONOMY OF CAMPYLOBACTER SPECIES}

In 1960, several studies have reported that the gold standard technique for delineation of the bacterial spp. is the whole-genome DNA-DNA hybridization. In 1980, the bacterial phylogeny has been studied depending on the degree of the ribosomal genes' similarities. The bacterial classification schemes have been developed, revised and became more popular (Debruyne et al. 2008).

In 1990, DNA sequencing became more common, therefore the molecular taxonomy researches and the molecular diagnosis of the bacteria including members of the genus Campylobacter have been increasingly used basing on the sequence similarity of $16 S r R N A$ gene (Debruyne et al. 2008 and Whitehouse $e t$ al. 2018).

The most common regions of DNA used for classification and differentiation of the bacteria such as Campylobacter spp. are the ribosomal genes, mainly $16 \mathrm{~S}$ rRNA (Linton et al. 1996). However, because of similarity in Campylobacter spp. sequences; the 16S rRNA gene sequence cannot be used for differentiation of genetically related spp. including $C$. coli and $C$. jejuni (On, 2001).

Since the past ten years, there was a considerable decline in DNA sequencing cost due to the advancement of many next-generation sequencing (NGS) techniques, which lead to the development of more robust phylogenetic trees by the whole-genome sequencing (WGS) utilization. Generally, for most of the published researches; the phylogenetic trees dependant on the 16S rRNA sequences correlate with the whole-genome spp. trees (Whitehouse et al. 2018).

\section{BIOLOGICAL CHARACTERISTICS OF CAMPYLOBACTER SPECIES}

\section{Phenotypic and biochemical criteria of Campylobacter species}

The members of genus Campylobacter are non-spore forming, small, slender, spirally curved Gram-negative bacilli. The size of a Campylobacter bacterium is $0.2-0.9 \mu \mathrm{m}$ in width and 0.5 to $5.0 \mu \mathrm{m}$ in length. Campylobacter could be present in chains or in pairs, showing up as gull-winged or S- shape appearance. The gull-wing gives them a darting motility. The motility of the genus Campylobacter is distinctively fast and darting in corkscrew appearance when seen by phasecontrast microscopy because of the existence of solitary unsheathed polar flagella at one or both ends of the bacterial cell. Among every single known spp., $C$. gracilis is the only nonmotile spp., while $C$. showae shows up as straight bacilli due to the appearance of numerous flagella (Goni et al. 2017 and Silva $e$ t al. 2018a).

Campylobacter spp. are successful foodborne bacteria and they require complex growth requirements which make them quite fastidious microorganisms (Bhunia, 2018). Campylobacters are mainly microaerophilic and they need limited oxygen, but these bacteria can be killed by normal atmospheric levels of oxygen (approximately 20\%). These criteria lead to difficult diagnosis of campylobacteriosis cases (Hu and Kopecko, 2018).

The ideal requirement for Campylobacter growth is the microaerophilic states of $3-10 \% \mathrm{CO}_{2}, 3-15 \% \mathrm{O}_{2}$ and $85 \% \mathrm{~N}_{2}$ (Goni et al. 2017). However, some spp. (C. rectus, $C$. concisus and C. curvus) favor anaerobic states for development (Kaakoush et al. 2015 and García-Sánchez et al. 2018).

All campylobacters develop at $37^{\circ} \mathrm{C}$ and cannot develop under $30^{\circ} \mathrm{C}$, but thermophilic campylobacters comprise C. lari, C. coli, C. upsaliensis and $C$. jejuni can develop at $42^{\circ} \mathrm{C}$. The ideal $\mathrm{pH}$ for the development of Campylobacter spp. is $5.5-8.0$, while $\mathrm{pH}$ values over 9 and beneath 5 are deadly for the bacterium (Silva et al. 2018b)

Campylobacter cannot ferment or oxidize sugars for energy, but instead it utilizes amino acids and tricarboxylic acid cycle (TCA) intermediates and it is resistance to bile (Llarena, 2015 and Llarena et al. 2015).

The thermophilic campylobacters reduce selenite, are oxidase positive and indole-negative. When exposed to urease test, thermophilic campylobacters are negative except for $C$. lari. Thermophilic campylobacters are catalase positive except for of $C$. upsaliensis (Goni et al. 2017).

Campylobacter spp. identification is difficult because of the fastidious development requirements and metabolic inactivity. The hydrolysis of sodium hippurate is a biochemical technique routinely utilized in discrimination between C. coli and $C$. jejuni. Even though, some strains of $C$. jejuni can give negative responses, $C$. jejuni can hydrolyzes sodium hippurate; but $C$. coli cannot hydrolyze the hippurate. Lately, molecular discrimination for example multiplex PCR is additionally needed to recognize Campylobacter spp. on the basis of variant genes (Vondrakova et al. 2014 and García-Sánchez et al. 2018).

\section{Physiology of Campylobacter species}

Campylobacter spp. can be killed by high temperatures reached in frying, cooking and pasteurization, but they can survive in sun-sheltered moist environment at $4^{\circ} \mathrm{C}$ (Llarena, 2015 and Llarena et al. 2015). Moreover, these bacteria can survive for many weeks at $4^{\circ} \mathrm{C}$ in water, but they survive at temperatures more than $15^{\circ} \mathrm{C}$ for only a few days. Campylobacters can survive at $-20^{\circ} \mathrm{C}$ for $2-5$ months, but they can suffer from a great fall in the number of viable bacteria due to thawing and freezing. Some spp. of the genus Campylobacter can survive in uncooked, salted meat if the primary contamination level due to their ability to survive at $4^{\circ} \mathrm{C}$ for several weeks in $2 \%$ sodium chloride solution (Hu and Kopecko, 2018).

Campylobacters don't have gene for cold shock protein, so they can't survive at temperatures below $30^{\circ} \mathrm{C}$. Additionally, they cannot survive in water activity below 0.987 (Facciolà et al. 2017). In spite of the disappearance of cold shock gene in C. jejuni isolates, these bacteria can survive and form biofilms at $13^{\circ} \mathrm{C}$ with the largest surface area in comparison with those formed at $42^{\circ}, 37^{\circ}$ and $20^{\circ} \mathrm{C}$ (Micciche et al. 2019).

Campylobacter spp. are more liable to be affected with stress conditions including radiation, disinfectants, acidity, freezing, heat, desiccation and drying than other pathogenic foodborne bacteria. This finding suggests that Campylobacter spp. are survived better in vivo than in vitro (Silva et al. 2018a) Some $C$. jejuni can survive under extreme environmental and aerobic conditions due to biofilm production, which facilitate its spread in the environment of food production and antimicrobial resistance (Platts-mills and Kosek, 2014 and Silva et al. 2018b)

Under prolonged cultivation and during stress conditions, Campylobacter become increasingly difficult to be cultured and the cells become coccoid. These bacteria can enter a viable but nonculturable (VBNC) form. Pre-enrichment as well as microaerobic growth condition and adding oxygen-quenching agents to 
the growth media such as charcoal and hemin can improve the recovery Campylobacter spp. (Hu and Kopecko, 2018).

\section{NATURAL HABITAT OF CAMPYLOBACTER SPECIES}

Campylobacter spp. are commonly found in the gut of different domestic animals for example, swine, sheep, cattle, cats and dogs and also the poultry caecum. Avian spp. especially, poultry has become the most well-known reservoir of Campylobacter spp. as a result of their high body temperature and they are responsible for an expected $80 \%$ of human Campylobacter infection (Silva et al. 2011; Epps et al. 2013 and Whiley et al. 2013). Thus, the gut mucosa of mammals and birds are considered the ideal site of bacterial multiplication and serve as a natural reservoir of Campylobacter spp. Campylobacter is a ubiquitous microorganism, which means that it can be found nearly everywhere as a commensal microorganism in the intestinal tract of different animals from the red kangaroos and Antarctic macaroni penguins to common housefly (Llarena, 2015).

Thermotolerant Campylobacter spp. (C. lari, C. jejuni and C. coli) are linked to the chicken intestine and to illness due to contaminated food, but in relation to the public health importance $C$. jejuni is believed to be the predominant spp (Cean et al. 2015 and Ugarte-Ruiz et al. 2018).

Few researches have reported that $C$. jejuni colonization of chicken intestinal tract may cause negative health implications. Therefore, Campylobacter is considered a commensal microorganism in the poultry intestine (Thibodeau $\boldsymbol{e}$ al. 2015 and Abd El-Hamid et al. 2019). Human campylobacteriosis can be caused by ingestion of raw or undercooked chicken meat contaminated with only few Campylobacter cells. The high genetic diversity and the wide range of hosts of Campylobacter spp. are making the attribution and tracing of the original source of infection difficult (Gölz et al. 2014 and Skarp et al. 2016).

Campylobacter spp. might be transmitted to humans by utilizing food and wate contaminated with theses bacteria or by coming in contact with carrier animals (fecal-oral way). Household pets are another possible transmission method for Campylobacter infection (Pintar et al. 2015). Despite the few studies available on the incidence of Campylobacter spp. in cats and dogs, these animals can be reservoir of several Campylobacter spp. such as $C$. showae, $C$. mucosalis, $C$. helveticus, C. lari, C. upsaliensis, C. jejuni, C. fetus, C. concisus, C. coli, C. gracilis and C. sputorum (Chaban et al. 2010)

Wild animals, particularly birds, have an essential role as reservoirs for Campylobacter spp., spreading Campylobacter in the environment to differen animals and humans (Whiley et al. 2013). Regardless the significance of these reservoirs, food-producing animals are the essential sources for campylobacteriosis (WHO, 2016).

Chicken is the most common reservoir of Campylobacter spp., therefore chicken carcasses and meat are the main vehicles for transmission of Campylobacte infection in human (Skarp et al. 2016). Many researches have been coordinated to detect Campylobacter origins and transmission methods to poultry with the major objective to identify the best intervention techniques to minimize the quantity of chicken flocks infected with Campylobacter spp. (Cox et al. 2012). The usual source of poultry contamination with Campylobacter spp. is the horizontal transmission. Poultry can get infected with Campylobacter spp. through the ingestion of water contaminated with this bacterium and also through coming in contact with Campylobacter infected animals including wild birds, poultry, other insects, household pets, feed, fecal dropping, farm equipment and vehicles (Hazeleger et al. 2008; Ellis-Iversen et al. 2009; Cox et al. 2012 and Georgiev et al. 2017)

Campylobacter spp. can spread rapidly in poultry flocks, mainly because of the coprophagic behavior of these animals and the high population density in breeding (Man, 2011 and Humphrey et al. 2014). Bird to bird transmission usually occurs in farms. Once infected, poultry remain infected until slaughter (van Gerwe et al. 2009 and Ingresa-Capaccioni et al. 2015).

Moreover, the vertical transmission of chicken is still controversial. Some researchers reported that Campylobacter spp. can't be transmitted through the egg shell (Fonseca et al. 2014). Interestingly, chickens maternal anti- Campylobacter antibodies disappeared after the $3^{\text {rd }}$ week of life, thus they usually become infected after the $4^{\text {th }}$ week of life (Humphrey et al. 2007). However, the vertical transmission is still a possible transmission method (Silva et al. 2018b).

Lamb, beef, pork and poultry meat and its products may become contaminated with Campylobacter spp. during slaughtering and its subsequent steps, because the microorganism found in the intestinal tract of infected animal can spread to their viscera, meat cuts and carcasses. In the chicken processing line, the stages with the highest contamination levels for are evisceration, plucking, defeathering, and scalding because of the meat exposure to the gut contents. Moreover, keeping the evisceration room temperature lower than $15^{\circ} \mathrm{C}$ can minimize the risk of contamination with these bacteria (Hue et al. 2010 and Ridley et al. 2011). Additionally, water chillers are another source for carcass cross-contamination originating from various batches of animals (Melero et al. 2012 and García-Sánchez et al. 2017).

Moreover, cross-contamination with Campylobacter spp. can occur in the postmarketing stages at home and in public areas like restaurants and retails usually through consumers processing and handling of contaminated raw chicken and its products. Thoroughly cooking of chickens before consumption can destruct the microorganism cell. On the other hand, raw chickens and ready-to-eat food crosscontamination can happen as a result of bad hygienic practices of consumers such as cleaning raw chicken with water, which can lead to the contamination of kitchen utensils and other ready-to-eat food (FSA, 2012)

Additionally, defrosting and storing chickens without hygienic precautions may increase the cross-contamination between foods by contact with dripping water from the defrosted meat (FSA, 2012; Hue et al. 2010 and Silva et al. 2018b). Interestingly, unpasteurized milk is another potential vehicle for human campylobacteriosis, due to the bad hygienic practices during milking which can result in milk fecal contamination. The Campylobacter incidence in dairy cow may be seasonal with a summer peak, while human Campylobacter infection outbreaks because of the contaminated milk consumption increases in the spring and fall (Elangro et al. 2012 and Mungai et al. 2015)

However, the Campylobacter transmission through contaminated raw fruit and vegetables is uncommon, it may be significant. Vegetables and fruits may get contaminated with Campylobacter spp. during distribution, packaging, processing, harvesting and production. Possible sources of contamination include dust, contact with infected animals, improper hygienic practices of the utensils, equipment and handlers, inadequately composted or natural manure, faeces, contaminated irrigation water and the survival or presence of the bacteria in the soil (Verhoeff-Bakkenes et al. 2011).

Besides food, water can act as an important environmental reservoir for Campylobacter spp., due to high survival rate of Campylobacter in water. Practices such as swimming in natural waters as well as ingestion of contaminated water are important sources of human Campylobacter infection outbreaks (Pitkänen, 2013 and Skarp et al. 2016).

Waterborne Campylobacter outbreaks can affect thousands of peoples, due to their need for potable water. Chlorination of water can be very effective against Campylobacter spp. Treatments of water need to take in their consideration the resistance of waterborne protozoa like Tetrahymena pyriformis that act as $C$. jejuni reservoirs (Newell et al. 2011 and Sibanda et al. 2018).

The public health significance of human Campylobacter infection requires the identification of the seasonal patterns of human campylobacteriosis (Friedrich $\boldsymbol{e}$ al. 2016). In temperate regions, seasonal peaks of campylobacteriosis are detected between July and August. These human campylobacteriosis peaks in the summer period are connected with high levels of chicken Campylobacter infection compared to winter, where insects are considered the regular vehicles of transmission between the food and the environment (Sahin et al. 2015 and Skarp et al. 2016). The causes behind the seasonal patterns of human campylobacteriosis are not clear yet. However, climate, changes in human behavior and an increase in bacterial reservoirs can affect the shedding and spread of this microorganism. There is a high risk of spreading human Campylobacter infections between urban and rural areas (Bronowski et al. 2014 and Williams et al. 2015)

\section{ISOLATION AND IDENTIFICATION OF CAMPYLOBACTER SPECIES}

No standard culture technique for Campylobacter spp. isolation is present and techniques used vary between research facilities. Campylobacter multiply more gradually than the other microbial flora in the intestine and need low oxygen levels. Therefore, it is hard to be isolated without utilizing selective media Additionally, enrichment techniques are important for food, environmental specimens and old stool specimens where the quantity of Campylobacter is low. However, an enrichment step is not typical essential for clinical samples (stoo specimens) (Chon et al. 2014; Goni et al. 2017 and Hu and Kopecko, 2018). A few enrichment broths have been defined to promote the growth of Campylobacter such as Preston broth, Bolton broth, Campylobacter enrichment broth, and Campy-thio (Baylis et al. 2000; Fitzgerald, 2015 and Galate and Bangde, 2015). The oxyrase enzyme addition to the selective broths plays a fundamental role in minimizing the oxygen levels and improving Campylobacter spp. isolation from naturally contaminated specimens, but a blood free enrichment broth does not contain the oxyrase enzyme (Abeyta et al. 1997 and Galate and Bangde, 2015).

Many effective selective media for Campylobacter spp. isolation are available such as Butzler, modified charchoal cefoperazone deoxycholate (mCCDA) and Preston agars are equally effective (Tran, 1998 and Galate and Bangde, 2015).

The most well-known selective agar utilized for isolation of Campylobacter is modified charcoal cefoperazone deoxycholate agar (mCCDA). The petri dishes are incubated at $42^{\circ} \mathrm{C} / 37^{\circ} \mathrm{C}$ for 2 days in anaerobic jars with gas-generating sachets, envelopes or Campy packs to maintain microaerobic condition comprising of 10\% CO2, 5\% O2 and 85\% N2 (Levin, 2007 and Hu and Kopecko, 2018). The colonies of Campylobacter are typically gray, flat irregular, and spreading in freshly prepared media. Selective culture is a fast, modest, and efficient technique for distinguishing $C$. jejuni and $C$. coli. After that, colonies suspected to be Campylobacter are cultured onto blood agar plates and the isolates are distinguished by motility, biochemical techniques and Gram's stain (Galate and Bangde, 2015 and Hu and Kopecko, 2018).

Hippurate hydrolysis test is the most common conventional characterization procedure, which is utilized for distinguishing $C$. coli from $C$. jejuni, but this 
technique may produce false negative results (Van Dyke et al. 2010). A few replacement and quick techniques have been documented for distinguishing Campylobacter spp. Polymerase chain reaction (PCR) is the best strategy for confirmation of Campylobacter spp. because the phenotypic responses are frequently atypical and hard to be read (Galate and Bangde, 2015).

Many studies reported the Campylobacter spp. detection by the use of culturebased techniques; however, these techniques have minimal bacterial recovery rates and they possibly underestimate the Campylobacter count in a given specimen, due to Campylobacter requirements for fastidious and complex growth condition. Biochemical techniques rely upon biochemical pathways and thei interruption can cause false results and product failure. These outcomes give false Campylobacter spp. prevalence (Yamazaki-Matsune et al. 2007 and Goni et al. 2017).

Denis et al. (1999) stated that biochemical tests give just $34 \%$ productivity contrasted with $100 \%$ for PCR assay. This methodology has essentially expanded the frequency of $C$. jejuni detection (8.1\% against 5.3\%) (Humphries and Linscott, 2015 and Goni et al. 2017).

For surveillance of antimicrobial resistance and epidemiological purposes, identification of Campylobacter spp. has become significant (Galate and Bangde, 2015). Therefore, many methodologies have been reported such as the conventional PCR assays, which utilized for identification of different genes such as $23 S$ rRNA gene for Genus Campylobacter, the hipO and mapA genes for $C$. jejuni and the glyA and ceuE genes for C. coli (Yamazaki-Matsune et al, 2007 and Goni et al. 2017).

A few molecular typing methods are essentially used for detection of intra- spp. differences (genetic diversity) among foodborne bacterial pathogens such as Campylobacter, to improve the comprehension of the epidemiology of these bacteria to start powerful control measures and to study the genetic relationship between the isolates of different sources (Hu and Kopecko, 2018).

The collective effort to meet this need during the most recent 30 years have led to different typing techniques for Campylobacter spp. including biotyping, serotyping, phage typing, gene-sequencing, multilocus enzyme electrophoresis typing (MLEE), repetitive sequence-based polymerase chain reaction (rep-PCR) which amplifies small DNA segments of the bacterial chromosome, pulsed-field gel electrophoresis (PFGE), fragment length polymorphism by amplification and restriction of specific genes (Such as flaA-RFLP), amplified fragment length polymorphism (AFLP), metabolic markers, whole genome sequencing (WGS), antimicrobial-resistance profiling and multilocus sequence typing (MLST) (Llarena et al. 2015 and Hu and Kopecko, 2018).

Interestingly, no golden standard genotyping method exists; but the perfect genetic typing technique (for attribution of sources) could be founded on the markers of the genome which give us clues about the host (genes that are associated with the animal reservoir), and inform us about the pathways (Llarena et al. 2015)

\section{PATHOGENESIS AND VIRULENCE FACTORS OF CAMPYLOBACTER SPECIES}

Campylobacter has a complex and not completely known mechanisms for survival to conquer the host barriers and to cause sicknesses in humans, interestingly studies on pathogenesis of Campylobacter are usually made with $C$. jejuni (Silva et al. 2018a). The dosage for Campylobacter infection is believed to be 350-10,000 cells and the infective dose is frequently correlated to the attack intensity. Campylobacter infections are most common in immunocompromised elder people and children (Epps et al. 2013; Bolton, 2015 and Bhunia, 2018).

After the consumption of contaminated water or food, Campylobacter needs to go through the gastric acid barrier of the stomach and the highly alkaline secretions from the bile duct in the upper small intestine (Hu and Kopecko, 2018). Interruption of the gastric acid barrier permits the pathogenic microflora like Campylobacter to survive and flourish. Thus, people with diminished gastric acidity such as those accepting antacid and inhibitors of proton pump can be at a high risk of campylobacteriosis (Same and Tamma, 2018).

Severe inflammation and cell damage are well established when Campylobacter attacks the distal ileum and colon epithelial cells after its arrival to the lower gastrointestinal tract; though in chickens, the cecum is the essential colonization site for Campylobacter (Meade et al. 2009). In developed countries, C. jejuni causes an invasive, inflammatory disease. However; in developing countries, Campylobacter causes a non-inflammatory watery diarrheal disease (Hu and Kopecko, 2018).

It is believed that host colonization, adhesion and invasion by Campylobacter needs chemotaxis and motility. Iron acquisition, resistance to gastric acids and bile salts and oxidative stress defense are important for growth and survival Bacterial toxins mediate inflammatory responses and tissue damage (Galate and Bangde, 2015).

Many putative survival and virulence factors are believed to be significant for pathogenesis and induction of gastroenteritis by Campylobacter spp. The molecular mechanism of Campylobacter infection is believed to be affected by the epidemiological and clinical features of the disease. Several genes have been identified as significant keys for the expression of pathogenicity. The cadF (adhesin gene), fla $\mathrm{A}$ (flagellin $\mathrm{A}$ gene), $d n a \mathrm{~J}$, and $r a c \mathrm{R}$ are pathogenic genes involved in colonization and adherence; $\operatorname{iamA}$ (invasion-associated gene A), vir $\mathrm{B} 11$ (virulence plasmid) and $c i a \mathrm{~B}$ are pathogenic genes responsible for invasion; $c g t \mathrm{~B}$ and wla $\mathrm{N}$ ( $\beta$-1,3-galactosyltransferases) are pathogenic genes involved in lipopolysaccharide production and $c d t \mathrm{C}, c d t \mathrm{~B}$ and $c d t \mathrm{~A}$, (cytolethal distending toxins $\mathrm{C}, \mathrm{B}$, and $\mathrm{A}$ ) are pathogenic virulence genes significant for the cytotoxin production expression (Bolton, 2015; Zhang et al. 2016 and GarcíaSánchez et al. 2018).

\section{Motility}

Motility is significant for Campylobacter to avoid harsh environmental conditions and genes associated with motility are mostly upregulated under stressful environments. The motility of bacteria needs flagella and a chemosensory system, which guides the flagella movement according to the surrounding gut environment. So, flagella are significant pathogenic factors that are required for the movement of the bacterium towards the epithelium surface, colonization, adhesion and invasion of the host epithelial cells. Campylobacter has characteristic helical shaped polar flagella at both or one end of the bacterial cell, which is responsible for the corkscrew torque impulsive motion in the viscid mucus, which allow the Campylobacter to go to its colonization site in the internal intestinal mucosa (Bhunia, 2018; García-Sánchez et al. 2018 and Silva et al. 2018a).

Additionally, the flagellum also has type III secretion systems (T3SS), which have a role in transporting nonflagellar proteins important for bacterial host interaction and pathogenesis. The T3SS are macromolecular complex component that permit Gram-negative microorganism to produce proteins through the outer and inner membranes in the absence of periplasmic intermediate, which serve as a molecular syringe. Many proteins can be transported through the flagellum like FspA, FlaC, CiaI, CiaC and $\mathrm{CiaB}$ (Neal-McKinney and Kronkel, 2012 and García-Sánchez et al. 2018).

Flagellins of Campylobacter can't stimulate proinflammatory cytokines, this feature permit Campylobacter to escape the host immune responses distinguishing it from many foodborne microorganisms such as Salmonella (Same and Tamma, 2018).

The flagellum composed of a helical shaped structure of the flagellin proteins, which include a hook-basal body and the extracellular filamentous structure. The hook-basal body consists of (i) the cytoplasm with a base implanted in it and the cellular internal membrane, (ii) the hook, which is localized in the surface and (iii) the periplasmic rod and its correlated ring components. The periplasmic rod is attached to the motor proteins, which provide energy for the flagellum movement. This system contains several proteins with various roles (Bolton, 2015; Bhunia, 2018 and García-Sánchez et al. 2018).

The hook- basal body is consisting of proteins such as the T3SS proteins (FliR FliQ, FliP, FliO, FlhB and FlhA), FliF, motor structures (MotB and MotA), motor switch proteins (FliY, FliN, FliM and FliG) and minor hook structures (FliM, FliK, FlgE, FlgH and FlgI). The extracellular filament is consisting of the minor flagellin subunit FlaB and the major subunits FlaA encoded by fla $\mathrm{B}$ and flaA genes, respectively that can be used for genotyping of Campylobacter spp. (Bolton, 2015 and Bhunia, 2018)

Additionally, CheY is another significant protein that is a response regulator essential for the turnover of the flagella. The mutation in essential genes like $f l h \mathrm{~B}, f l h \mathrm{~A}$, fla $\mathrm{B}$ and fla $\mathrm{A}$ prevents the $\mathrm{FlaB}$ or FlaA proteins production, which lead to the disruption motility, pathogenesis and invasion (Yao et al. 2017; Bhunia, 2018 and García-Sánchez et al. 2018)

\section{Chemotaxis}

Chemotaxis is a normal reaction of the motile bacteria to be driven towards chemoattractants by the use of chemosensors. The chemosensors are two structures: methyl-accepting chemotaxis proteins (MCPs) and signal transduction pathway, which depends on histidine kinase and consists of chemotaxis proteins such as CheZ, CheY, CheW, CheR, CheB and CheA (Bhunia, 2018). The flagellar proteins are regulated by chemosensing proteins, which regulate the bacterium directional movement that drive the bacteria to move towards the favorable environmental conditions and avoid unfavorable ones (Rowe and Madden, 2014).

Campylobacter motility towards glycoproteins and mucins on the surface of the mucus membrane can favor the intestinal colonization of Campylobacter. Moreover, there is other chemoattractant such as succinate, lactate, malate formate, serine, pyruvate, glutamate, cysteine, asparagine, aspartate, $\alpha$ ketoglutarate, acceptors and donors of electrons, other metabolic substrates and amino acids (Bolton, 2015; Bhunia, 2018 and Silva et al. 2018a)

\section{Adhesion}

After bacteria have passed the mucosal layer, they bind to the gut epithelial cells Adhesion to the epithelial cells is a complex mechanism, where adhesions on the microorganism cell surface attach to the receptors of the host cells resulting in specific and irreversible binding. This cellular adherence of the gut is prior to 
colonization and essential for Campylobacter resistance to the intestinal expulsion and peristalsis (Ganan et al. 2012 and Silva et al. 2018a).

Many adhesion proteins of Campylobacter spp. that present on the bacterial cel surface have been identified. CadF protein $(37 \mathrm{kDa})$ is a protein presents on the outer membrane of Campylobacter, it regulates the adhesion of the bacterial cell by attaching to fibronectin, which is an extracellular glycoprotein present in the intestinal tract. This reaction stimulates a signaling pathway, which result in the activation of the Cdc42 and GTPases Rac1 that stimulate the bacterial cell to internalize through actin-mediated induced phagocytosis. Many researches have showed that mutation in this protein can prevent Campylobacter colonization (Bhunia, 2018; García-Sánchez et al. 2018 and Silva et al. 2018a).

Additionally, other proteins have been detected in the adhesion mechanism like the surface-exposed lipoprotein, JlpA (42.3 kDa), fibronectin-like protein A FlipA, Campylobacter adhesion protein A; CapA (autotransporter lipoprotein), and periplasmic binding protein; Peb3 (transport protein), Peb4 (chaperoneCadF transporter protein) and Peb1 (21 kDa protein). The JlpA attaches to the eukaryotic Hsp90 (90 kDa) and causes signal transduction in the host cells. The lipooligosaccharide (LOS) and lipopolysaccharide (LPS) are also contributed to serum resistance and bacterial adhesion (Bolton, 2015; Bhunia, 2018 and Silva et al. 2018a).

Heat-shock proteins of Campylobacter spp., ClpB, DnaK, DnaJ and GroESL, help in the survival and thermotolerance of the bacteria in the poultry gut because the temperature of the intestinal tract is about $42{ }^{\circ} \mathrm{C}$. Interestingly, DnaJ is the only heat-shock proteins, which have a direct role in the colonization of Campylobacter (Bhunia, 2018).

Several studies stated that there is a relation between the degrees of Campylobacter adherence to the cultivated cell line and the intensity of campylobacteriosis in infected patients (García-Sánchez et al. 2018)

\section{Invasion}

Campylobacter invasion ability is a significant factor in the pathogenesis. The clinical symptoms of acute campylobacteriosis are correlated with the invasion of epithelial cells. The flagellum has significant role during the invasion of host cell through helping the nonflagellar proteins secretion by its T3SS channel (Bhunia, 2018). Campylobacter invasion antigens (Cia) are group of proteins, which have a vital role in the survival and invasion of host cells and they are delivered to the host cells cytosol through a flagellar T3SS. Therefore, mutations in the flagellar proteins lead to reduction of this invasion ability (Barrero-Tobon and Hendrixson, 2012 and García-Sánchez et al. 2018).

Moreover, there are three Cia proteins; CiaI, which has a fundamental role in Campylobacter survival inside host cell, $\mathrm{CiaC}$ that is essential for maximal invasion of INT-407 cells and CiaB that is important for target cells adherence. In the recent years, a $4^{\text {th }}$ protein, $\mathrm{CiaD}$ has been showed to have a key role in the host cells invasion (Samuelson et al. 2013). Additionally, mutation in $\mathrm{CiaB}$ protein results in reduction of the invasion ability through minimizing the adherence and the possible invasion. Moreover, there are other proteins including FspA, VirK, HtrA (a chaperone protein), CeuE, IamA (invasion-associated protein A) and $\mathrm{FlaC}$, which also play a role in the invasion of host cell, but the mechanisms are not fully known yet (Bolton, 2015 and García-Sánchez et al. 2018). Moreover, some Campylobacter isolates have a plasmid with high molecular weight, pVir, which has been reported to be correlated to bloody diarrhea. pVir has been reported to have vital role in the invasion of host cell and it is encoded by virB11 gene (Same and Tamma, 2018).

\section{Toxin production}

After the internalization, Campylobacter enters a vacuole or a membrane-bound structure to escape the host immune system and survive inside the epithelial cell for long period of time until the conditions become favorable for cytotoxic response induction (Rowe and Madden, 2014).

Campylobacter secretes many toxins and the main toxin is the cytolethal distending toxin (CDT), which encoded by a three gene operon (cdtABC). The CDT composed of three toxins with identical molecular weight, CdtB (29 kDa), CdtC $(21 \mathrm{kDa})$ and CdtA $(30 \mathrm{kDa})$. So, it is named a tripartite "AB2" toxin, where $\mathrm{CdtB}$ toxic subunit is the enzymatically active one, while the $\mathrm{CdtC}$ and CdtA comprise the "B2" subunit that have a role in binding to the receptor of the cell membrane and the CdtB internalization (Bolton, 2015 and Bhunia, 2018).

The $\mathrm{CdtB}$ subunit is internalized in the nucleus after its translocation in cytoplasm of the host cell (Silva et al. 2018a). Additionally, CdtB has a nuclease activity, which stimulates damage of DNA through double strand breaking. This will result in stopping the cycle of the cell, mainly in the mitosis G2/M transition stage, which affect the cell division and lead to distension of the cell and apoptotic cell death (Koolman et al. 2016 and García-Sánchez et al. 2018).

The CDT is believed to cease the crypt cells maturation into effective villous epithelial cells; so, it stops the intestinal absorption for a short time and causes diarrhea. CDT is trypsin-sensitive and affected by heating $\left(70{ }^{\circ} \mathrm{C}\right.$ for $30 \mathrm{~min}$ ) Moreover, Campylobacter have other toxins like hepatotoxin, pore-forming hemolysin, a shiga-like toxin, which disrupt the protein production and choleralike enterotoxin that activates cAMP (Bhunia, 2018).

\section{Iron acquisition}

The capability of Campylobacter to take iron from transferrin in the host serum and lactoferrin from the mucosa is significant for pathogenesis and persistence of Campylobacter in the host cells and the effective colonization of the intestinal mucosa including many receptors on the cell membrane, regulators and transporter proteins (Hermans et al. 2011; Bolton, 2015 and Bhunia, 2018).

Campylobacter cannot produce siderophores, but it uses enterochelin, ferrichrome and siderophores secreated by other microorganisms to obtain iron. Thus, Campylobacter will have a competitive advantage taking into account the several genes involved in regulation of iron acquisition and homeostasis despite its small DNA. Moreover, there are two important regulator proteins for iron uptakes include PerR (peroxide stress regulator) and fur (ferric uptake regulator) (Miller et al. 2009; Bhunia, 2018 and García-Sánchez et al. 2018).

\section{Carbohydrate structures}

Four various categories of carbohydrate structures like N- and O- linked glycans, capsular polysaccharides (CPS) and LOS can be established on the Campylobacter cell surface. The LOS molecule is a significant virulence factor associated with the immunological symptoms. It is composed of lipid A and a core oligosaccharide and it has been related to various activities such as protection from killing by complement-mediated, invasion, host cell adhesion and immune evasion. Adding a sialyl group to the LOS molecule will maximize the invasive ability and minimize the Campylobacter strains immunogenicity (Bolton, 2015 and García-Sánchez et al. 2018).

Campylobacter sialylated LOS, which have the ability to mimic the human antigens, such as wla $\mathrm{N}$ ( $\beta-1,3$-galactosyltransfrase) and $c g t \mathrm{~B}$ genes those mimics the myelin sheath of the nervous cells' ganglioside. When Campylobacter enter the host cells, an antibody is produced against the sialylated LOS by the host immune system. These antibodies can cause nerve cell demyelination, blockage of nerve impulse and progressive weakness in the muscles of the respiratory system and limbs, which lead to the emergence of Miller Fisher syndrome and Guillain-Barré syndrome (GBS). Most GBS patients had campylobacteriosis with strains have LOS belonging to the locus class A (Revez and Hänninen, 2012 and García-Sánchez et al. 2018).

Additionally, CPS have been reported to have several functions including contribution to the gut virulence, formation of biofilm and protection of Campylobacter from harsh environmental conditions such as maximize its resistance to desiccation (Nachamkin et al. 2008 and García-Sánchez et al. 2018). In $C$. jejuni genome sequencing, the kps genes were detected as genes responsible for capsule biosynthesis (Zilbauer et al. 2008). Strains with the $k s p \mathrm{M}$ gene mutants that encode a protein responsible for capsular polysaccharide transport will minimize Campylobacter invasiveness, colonization and decrease its resistance to human serum (Bolton, 2015 and Silva et al. 2018a).

Concerning glycosylation of protein, Campylobacter is the main microorganism that has both $\mathrm{N}$ - and $\mathrm{O}-$ linked systems (Jeon et al. 2010). Moreover, the Campylobacter $\mathrm{N}$-linked glycosylation system plays a key role in posttranslational modification of more than 60 periplasmic proteins such as flagellin and it is encoded by the pol multigene locus found in Campylobacter. The surface proteins $\mathrm{N}$-linked glycosylation are responsible for Campylobacter protection against gut proteases and avoiding immune system of the host. On the other hand, O-linked glycosylation has a significant role in flagellar glycosylation and only limited to the flagellin subunits (Bolton, 2015 and García-Sánchez et al. 2018).

\section{Regulation of virulence genes}

Colonization and thermotolerance in the intestinal tract are regulated by regulatory system composed two components including a response regulator (RR) and a histidine kinase (HPK) sensor. The RR is phosphorylated by HPK and responsible for the regulation of the expression of RacR, CheY and other proteins those are important for thermotolerance at $37^{\circ}-42^{\circ} \mathrm{C}$ and colonization. Moreover, the acquisition of iron is regulated by PerR and Fur proteins. Additionally, the fla A regulon, which have a key role in synthesis of Campylobacter flagella, is regulated by a signal transduction system composed of two components (FlgS/FlgR) (Bhunia, 2018).

\subsection{Campylobacter survival in stress environment}

The foodborne microorganisms are exposed to stressful environment both inside and outside of the host organism. The expression of stress response mechanisms by the foodborne pathogens has a significant role in their persistence in different habitat (Silva et al. 2018a).

Unlike other foodborne pathogens, Campylobacter doesn't possess several adaptive responses to stressful environment. These bacteria do not have the rpoS gene, which is a sigma factor in the stationary stage that encodes for the RpoS (sigma 38) global regulator that is associated with virulence genes and the transcription of stress response (Silva et al. 2018a). However, Campylobacter have few adaptive responses for reactive oxygen spp., acid tolerance and heat shock that permit them to persist in the stressful environmental conditions (Bolton, 2015 and Dasti et al. 2010). Despite lack of many stress response 
mechanisms, fastidious growth requirements and its sensibility to environmental stressors, these bacteria can cause a public health hazard due to its persistence in the food chain (Silva et al. 2018a).

\section{RESISTANCE OF CAMPYLOBACTER SPECIES TO ANTIMICROBIAL AGENTS}

Bacterial resistances are mainly caused because of the aimless utilization of the antibiotic agents in human disease treatment as well as its exaggerated use in animal production (Silva et al. 2018a). Recently, the emergence of antimicrobial resistance in $C$. coli and $C$. jejuni originating from food of animal origin has become a critical public health problem worldwide (EFSA, 2017).

Campylobacteriosis is characterized by a self-limited diarrhea; in this way, antimicrobial therapy is not usually recommended. But antimicrobial therapy is required in case of serious infection, which may be systemic or prolonged. Campylobacter is a zoonotic pathogen; subsequently, Campylobacter resistan strains will cause serious problems because the most well-known antimicrobial agents would be useless against campylobacteriosis (Bhunia, 2018).

Campylobacter is a commensal bacterium in the intestine of different domestic animals and this led to their exposure to several classes of antimicrobial agents. Between these antimicrobial agents, quinolones as enrofloxacin or ciprofloxacin is believed to be associated with causing high resistance rates in food products and farms; so, the US Food and Drug Administration (FDA) has restricted fluoroquinolones utilization in USA chicken industry as a growth supplement (Bhunia, 2018 and Same and Tamma, 2018). Additionally, the natura competence and hypervariable genomic structure of Campylobacter lead to an extensive genomic diversity which may be another cause of antibiotic resistances (Goni et al. 2017 and García-Sánchez et al. 2018).

Campylobacter is resistant innately to vancomycin, nafcillin, trimethoprim, sulfamethoxazole, oxacillin and cloxacillin. But, different kinds of resistance may be an outcome of the use of antibiotics in animal and human treatment (Llarena, 2015 and Llarena et al. 2015). Four main methods are implicated in Campylobacter resistance to antibiotics including (i) production of enzymes that modify or inactivate antimicrobial agents (e.g., $\beta$-lactamase), (ii) changing the antibiotic recipient and/or its expression (e.g., $23 S$ rRNA or gyrA genes mutations), (iii) antimicrobial efflux pumps which actively eject the antimicrobial agents from the cell (e.g., multidrug efflux pumps, CmeABC), and (iv) minimize the antimicrobial permeability, so the antimicrobial cannot reach its target due to unique membrane structures (i.e., the major outer membrane porin expression or MOMP) (Luangtongkum et al. 2010 and García-Sánchez et al. 2018).

Finally, Campylobacter antimicrobial resistance may be endogenous/ inherited to the bacterium, or exogenous by genetic transfer from other microorganisms or mutation. Campylobacter have many mechanisms for resistance making it resistant to the main classes of antibiotics including: aminoglycosides, tetracyclines, quinolones, macrolides and $\beta$-lactams (Shen et al. 2018; Silva et al. 2018a and Whitehouse et al. 2018).

\section{Multidrug efflux pump system}

The Campylobacter multidrug efflux (CME) pump usually mediates Campylobacter resistance to heavy metals, bile salts and a wide range of other antibiotics. So, it is an active method for these agents to be pumped extracellulary, consequently avoiding their accumulation inside the bacterial cell, which essential for the bacterial cell death (Kurinčič $\boldsymbol{e t}$ al. 2012). The CME pump is encoded by the cmeABC operon that is composed of a periplasmic fusion protein; $\mathrm{CmeB}$ a protein on the outer membrane, $\mathrm{CmeC}$ an efflux transporter on the inner membrane that belongs to the superfamily of resistancenodulation-cell division and $\mathrm{CmeA}$ that bridges $\mathrm{CmeC}$ and $\mathrm{CmeB}$ (Bolton, 2015 and García-Sánchez et al. 2018)

CmeR is a transcription repressor protein, which modulates the expression of the cmeABC operon through the cj0561c gene inhibition. The CME pump has a fundamental role in $C$. jejuni intrinsic resistance to variety of structurally unrelated antibiotics (Bolton, 2015 and Whitehouse et al. 2018).

Several studies have demonstrated the significant contribution of this efflux system in the antimicrobial resistance to

ampicillin, macrolides, tetracycline and quinolones (Iovine, 2013 and Silva et al. 2018a).

\section{Quinolones}

The European Food Safety Authority (EFSA) stated that Norway and Denmark are the only European state members, which have very high ciprofloxacin resistance levels. Five member states stated increased trends in $C$. jejuni fluoroquinolone resistance. Moreover, 11 out of 17 member states countries showed high levels of $C$. coli ciprofloxacin resistance (80-100\%) with 2 reporting countries have increased trends during the period from 2013-2015 (EFSA, 2017). According to the high level of fluoroquinolones acquired resistance, they should not be used for treatment of patients suffering from campylobacteriosis (EFSA, 2017). Thus, other antimicrobial agent has been required for treatment of human campylobacteriosis such as macrolides (azithromycin and/or erythromycin) and probably soon fluoroquinolones may become disused. Several researches have showed a correlation between the increased resistance of Campylobacter isolates among chicken and human and the fluoroquinolone use in poultry industry (Luangtongkum et al. 2010; Shen et al. 2018 and García-Sánchez et al. 2018). Campylobacter quinolones resistance is mediated by the CmeABC efflux pump and also through a single point mutation in the gyrA gene determining area of quinolone resistance (Iovine, 2013; Shen et al. 2018 and Whitehouse et al. 2018).

\section{Tetracyclines}

Campylobacter resistances to tetracycline have been mediated by the protein of ribosomal protection; TetO that is encoded by the tet $(\mathrm{O})$ gene. The tet $\mathrm{O}$ gene is common in $C$. coli and $C$. jejuni. The TetO protein identifies the bacterial ribosome open A site and attach to it to cause conformational changes, which lead to the detachment of tetracycline molecule from the ribosome (Luangtongkum et al. 2010 and García-Sánchez et al. 2018).

Campylobacter tetracycline resistance has two methods including: (i) multidrug efflux pump system and (ii) changing the ribosomal target of tetracycline Usually the tet $\mathrm{O}$ gene is found in the plasmid; but some Campylobacter isolates have a tet $\mathrm{O}$ gene detected on the chromosome (Iovine, 2013 and Whitehouse et al. 2018).

\section{Aminoglycosides}

Aminoglycosides antimicrobial agents include streptomycin, tobramycin neomycin, amikacin, kanamycin and gentamicin. There are two mechanisms for aminoglycosides to maintain their antimicrobial activities: (i) proofreading interference which lead to dysfunctional proteins due to using wrong amino acids and (ii) interference with the early peptide chain translocation from the ribosomal A site to the $\mathrm{P}$ site, which result in its premature end (Iovine, 2013 and Yao et al. 2017).

Campylobacter jejuni aminoglycoside resistance is mainly occurred through aminoglycoside-changing enzymes (Sat, aacA AadE, AphD and AphA) that are encoded by plasmids genes. Moreover, the efflux pump system contribution is not fully understood yet (Iovine, 2013 and García-Sánchez et al. 2018).

The first report of Campylobacter resistance to aminoglycosides was in C. coli and has been mediated by a 3'-aminoglycoside phosphotransferase that is encoded by the aphA-3 gene. Moreover, other genes have also been identified in Campylobacter spp. such as genes conferring to kanamycin resistance (aphA-7 and $\operatorname{aph} \mathrm{A}-1)$, streptothricin resistance (sat) and streptomycin resistance $(\operatorname{aad} \mathrm{E})$ (Silva et al. 2018a and Whitehouse et al. 2018).

\section{Macrolides}

European food safety authority (EFSA) studies reported that Campylobacter resistance to macrolides has been increased in the last years and it is found usually at high levels in several European Union members. Historically, the incidence of $C$. jejuni macrolides resistance has been low, but there are many methods for Campylobacter to acquire macrolides resistance (EFSA, 2017).

Campylobacter has four main mechanisms for macrolides resistances including (i) efflux by CmeABC efflux pump and possibly others, (ii) methylation of the ribosome encoded by erm $\mathrm{B}$ gene, (iii) ribosomal proteins target mutations and (iv) mutation in the $23 S r R N A$ gene (Bolinger and Kathariou, 2017). The ribosomal methylation pathway has been reported recently in one avian $C$. coli isolate in Spain. This was the first report about the Campylobacter erm $\mathrm{B}$ gene in Europe. This isolate had an elevated level of erythromycin resistance (MIC1024 $\mathrm{mg} / \mathrm{L}$ ) and the erm $\mathrm{B}$ gene was detected among a multidrug resistance island having five genes for antibiotic resistance. Additionally, this isolate was gentamicin susceptible, but it was resistant to streptomycin, tetracyclines, ciprofloxacin and nalidixic acid (EFSA, 2017 and Shen et al. 2018).

Macrolides inhibit the bacterial ribosome protein synthesis by acting on the 50S ribosomal subunit and disrupting the protein synthesis of the bacteria, which result in ribosomal conformational changes and premature termination of the peptide chain elongation. Additionally, the Campylobacter $23 \mathrm{~S}$ rRNA gene has three chromosome copies. In erythromycin resistant Campylobacter strains, al copies have mutations related to macrolide resistance (Wieczorek and Osek, 2013 and García-Sánchez et al. 2018).

Moreover, the synergy between mutations and the CmeABC efflux pump system has fundamental role in ketolides (telithromycin) and macrolides (tylosin, azithromycin clarithromycin and erythromycin) resistance in $C$. coli and $C$. jejun (Luangtongkum et al. 2010; Shen et al. 2018 and García-Sánchez et al. 2018). Campylobacter has another method for macrolide resistance includes an alteration in the permeability of the cell membrane mediated by the expression of the MOMP that is encoded by porA gene. Porins are proteins in the external membrane of Gram-negative microorganisms, which made pores across the membrane that permit the hydrophilic molecules passive diffusion like severa antimicrobial agents. The MOMP make a small pore, which is selective for positively charged ion, in $C$. coli and $C$. jejuni this result in minimizing the 
passage of most antimicrobial agents with a negative charge or those which have a molecular weight more than $360 \mathrm{kDa}$ (Iovine, 2013 and Silva et al. 2018a).

\section{$\beta$-lactams}

$\beta$-lactams resistance in Campylobacter spp. is usually mediated by $\beta$-lactamases enzymes, which breakdown the $\beta$-lactams structure. Additionally, some Campylobacter strains have other mechanisms for $\beta$-lactams resistance such as cation-selective MOMP and efflux pump system (Iovine, 2013). Campylobacter are usually resistant to many $\beta$-lactams antibiotics such as cephalosporins and penicillin (Wieczorek and Osek, 2013; Silva et al. 2018a and Whitehouse et al. 2018).

\section{PUBLIC HEALTH SIGNIFICANCE OF CAMPYLOBACTER SPECIES}

The human Campylobacter infection of incredible public health importance is Campylobacter gastroenteritis caused mainly by $C$. jejuni and sometimes by $C$. coli. Chickens are distinguished as the principle reservoirs of thermophilic Campylobacter spp. Furthermore, chickens are answerable for an expected $80 \%$ of Campylobacter infection in human. Chickens are believed to be asymptomatic carriers (Goni et al. 2017 and García-Sánchez et al. 2018).

Campylobacter spp. can colonize large proportion of poultry flocks. An European Union baseline research stated that campylobacter was detected in $75.8 \%$ of broiler carcasses, $71.2 \%$ of cecal contents of broiler batches were also contaminated with campylobacter (FSA, 2012) and there was a $61.3 \%$ prevalence rate of Campylobacter in samples of chicken skin at the retail level, $18.6 \%$ of which had Campylobacter counts more than 1000 CFU/g (PHE, 2017 and Gölz et al. 2018).

Despite, campylobacteriosis severity rate is low $(0.03 \%)$, the quantity of human Campylobacter infection cases is elevated. Interestingly, human Campylobacter infection is the third most common reason of mortality between the foodborne microorganisms and death can occurs in immunocompromised patients suffering from liver diseases, cancer and acquired immunodeficiency syndrome (AIDS (EFSA, 2017; Bhunia, 2018 and García-Sánchez et al. 2018)

Campylobacteriosis are mainly self-limiting and sporadic. Gastroenteritis caused by Campylobacter is distinguished by high body temperature, vomiting, weight loss, abdominal pain/cramps, headache and acute watery and sometimes bloody diarrhea (CDC, 2014 and Skarp et al. 2016).

Additionally, Campylobacter can cause post infectious immune disorders like Guillain Barré syndrome (GBS), which is a nervous system disorder distinguished by an advanced weakness and flabby paralysis in the extremities and it may cause paralysis in the respiratory muscles, reactive arthritis (inflammation of joints) and Miller Fisher syndrome (MFS) which is characterized by coulometer weakness (areflexia and ataxia) and the vision problem (ophthalmoplegia) (Bhunia, 2018 and Whitehouse et al. 2018).

In developing countries, campylobacteriosis is hyperendemic and the Campylobacter infection is symptomatic and occurs almost exclusively and repeatedly in young children and infants. Subsequent infections can be asymptomatic, which make the symptomatic infection rare in adults or older children (Same and Tamma, 2018).

Campylobacteriosis is usually sporadic, but there were many reported outbreaks. Koppenaal et al. (2017) stated a C. fetus outbreak due to ingestion of products of unripen cheese, which made from contaminated raw sheep's milk. Burakoff $\boldsymbol{e}$ al. (2018) detected an outbreak of $C$. jejuni as a result of drinking contaminated unpasteurized milk. Calciati et al. (2012) reported a campylobacteriosis outbreak in 75 school children in Spain. Animals have been also identified as human campylobacteriosis sources due to the appearance of multidrug-resistan Campylobacter infections outbreak in several states that is related to the contact with infected puppies in a pet store. This outbreak occurred in 17 states in USA with 23 hospitalizations from 113 reported infected cases (García-Sánchez et al. 2018 and CDC, 2018).

Globally, 166 million Campylobacter cases per year have been reported, but there is a great difference by the region. In region where surveillance programs for foodborne illness are well settled, the campylobacteriosis yearly rate is high In New Zealand, 152.9 cases/ 100,000 populations were stated (Ministry for Primary Industries, 2015). This was followed by Australia and Europe where 93.5 (NNDSS, 2016) and 59.8 (European Centre for Disease Prevention and Control, 2016) cases/ 100,000 populations were reported. In USA, 14 cases/ 100,000 populations were stated yearly (CDC, 2017); however, in Canada, 23 cases/ 100,000 populations were reported in 2015 (Public Health Agency of Canada, 2017; Silva et al. 2018a and Whitehouse et al. 2018).

Interestingly, there is a significant difference in the epidemiology of campylobacteriosis between developed and developing nations. In developing countries, Campylobacter is not the most common cause of the bacterial foodborne illness, because in the developing nations there aren't national programs for surveillance of Campylobacter infection, thus the state of Campylobacter infection is difficult to be evaluated in these countries (WHO, 2015 and García-Sánchez et al. 2018). In the developing nations the knowledge about the status of Campylobacter infection is obtained from research articles on Campylobacter isolation from different specimen (Silva et al. 2018a).
PHYTOCHEMICALS AS INTERVENTION STRATEGIES USED TO REDUCE CAMPYLOBACTER SPECIES IN POULTRY PRODUCTION

Chickens are believed to be answerable for up to $80 \%$ of human Campylobacter infection. Therefore, intervention procedures have been developed for controlling Campylobacter in chickens at the farm level to minimize the products contamination and accordingly the incidence of human campylobacteriosis (Upadhyay et al. 2019).

Since ancient times, phytochemicals have been utilized as food supplements, enhancers of flavor and natural preservatives in numerous cultures. Most of phytochemicals are produced in plants as secondary metabolites due to the interactions between plants and their surrounding environment. The phytochemicals do not participate with any principle metabolic procedures in plants, but they possibly increase the immunity and capacity of these plants to persist in stressful environment and pathogenic infection (Upadhyay et al. 2017). Several phytochemicals possess important antimicrobial activities including betaresorcylic acid (from Brazilian berries and wood), eugenol (from clove oil), trans-cinnamaldehyde (from cinnamon bark), caprylic acid (from coconut oil as medium-chain fatty acid), thymol and carvacrol (from oregano oil) (Wagle et al. 2017a and Upadhyay et al. 2019).

Recently, a great expansion in the consumer preference towards natural products has been reported. Therefore, several scientists concentrated on utilizing products from plant origin as an alteration to antimicrobial agents in food from animal origin. Several phytochemicals have an antimicrobial efficacy by disrupting the bacterial cell wall and membrane integrity, which may cause a leakage of cellular contents and cell death (Upadhyay et al. 2019).

Beta-resorcylic acid (2, 4 dihydroxybenzoic acid) is a polyphenolic complex which is broadly distributed as a secondary metabolite between the angiosperms for plants protection from microbial infection and it is also utilized as food additives and flavoring agent. It is classified under "Everything Added to Food in the United States" by the US-FDA (EAFUS; Cas no. 89-86-1) (Food and Drug Administration, 2013 and Wagle et al. 2017a). Former researches have indicated that beta-resorcylic acid is efficient in minimizing principle foodborne microorganisms such as Salmonella species (Mattson et al. 2011), Listeria monocytogenes (Upadhyay et al. 2013a), Escherichia coli O157:H7 (Baskaran et al. 2013) and $C$. jejuni (Wagle et al. 2017b) in food products.

Eugenol is another polyphenol compound that is the significant antimicrobial component found in the oil of cloves (Syzgium aromaticum/ Eugenia caryophyllus) (Upadhyay et al. 2017 and Wagle et al. 2019) and it is additionally attractive to consumers as a substitution for the antimicrobial agents, since it is considered acceptable for organic and non-conventional uses (Micciche et al. 2019). Additionally, eugenol has exhibited an importan antimicrobial action against foodborne microorganisms such as Salmonella spp. (Upadhyay et al. 2013b), Escherichia coli (Ghosh et al. 2013), Listeria monocytogenes (Upadhyay et al. 2015) and C. jejuni (Wagle et al. 2019).

Moreover, recent researches have demonstrated that beta-resorcylic acid and eugenol can change microbial virulence in $C$. jejuni by minimizing $C$. jejuni attachment and invasion to the epithelial cells in the intestinal tract and by changing the expression of virulence factors such as motility and cytolethal distending toxins (Upadhyay et al. 2017 and Wagle et al. 2017a). Eugenol and Beta-resorcylic acid are likewise classified by the FDA as GRAS (generally recognized as safe) with fast biodegradation in the environment and minima cytotoxicity, which making them safe and efficient replacement to the antimicrobial agents (Food and Drug Administration, 2012 and 2013 and Wagle et al. 2019).

\section{CONCLUSION}

Campylobacter spp., mainly $C$. jejuni have become the leading cause of bacteria foodborne enteritis worldwide. Human Campylobacter infection is caused by the consumption of contaminated poultry meat and meat products.

Over the last decade, many researches have been applied to study the biology, antimicrobial resistance, pathogenicity, virulence and epidemiology of Campylobacter spp. to found the ideal control strategies of these bacteria and thus reduce Campylobacter infection in humans. However, the lack of surveillance programs in developing countries making it difficult to control campylobacteriosis; therefore, efforts to survey and control these bacteria should be increased worldwide. There are various methods to control these pathogens, but recent researches prefer the use of phytochemicals such as beta resorcylic acid and eugenol due to their antimicrobial properties and their ability to down regulate the expression of several virulence genes, which lead to minimizing $C$. jejuni attachment and invasion to the epithelial cells in the gastro intestinal tract.

\section{REFERENCES}

Abd El-Hamid MI, Abd El-Aziz NK, Samir M, El-Naenaeey EY, Abo Remela EM, Mosbah RA \& Bendary MM (2019). Genetic Diversity of Campylobacter jejuni Isolated from Avian and Human Sources in Egypt. Frontiers in Microbiology, 10, 2353. http://dx.doi.org/10.3389/fmicb.2019.02353 
Abeyta, C., Trost, P. A., Bark, D. H., Hunt, J. M., Kaysnet, C. A. \& Wekell, M M. (1997). The use of bacterial membrane fractions for the detection of Campylobacter species in shellfish. Journal of Rapid Methods and Automation in Microbiology, 5 (3), 223-247. http://dx.doi.org/10.1111/j.17454581.1997.tb00165.x

Barrero-Tobon, A. M., \& Hendrixson, D. R. (2012). Identification and analysis of flagellar coexpressed determinants (Feds) of Campylobacter jejuni involved in colonization. Molecular Microbiology, $84 \quad$ (2), 352-369. http://dx.doi.org/10.1111/j.1365-2958.2012.08027.x

Baskaran, S. A., Upadhyay, A., Kollanoor-Johny, A., Upadhyaya, I., Mooyottu, S., Roshni Amalaradjou, M. A., Schreiber, D. \& Venkitanarayanan, K. (2013). Efficacy of Plant-Derived Antimicrobials as Antimicrobial Wash Treatments for Reducing Enterohemorrhagic Escherichia coli O157:H7 on Apples. Journal of Food Science, 78 (9), M1399-M1404. http://dx.doi.org/10.1111/17503841.12174

Baylis, C. L., MacPhee, S., Martin, K. W., Humphrey, T. J., \& Betts, R. P. (2000). Comparison of three enrichment media for the isolation of Campylobacter spp. from foods. Journal of Applied Microbiology, 89 (5), 884 891. http://dx.doi.org/110.1046/j.1365-2672.2000.01203.x

Bhunia, A. K. (2018). Campylobacter and Arcobacter. In: Foodborne Microbial Pathogens: Mechanisms and Pathogenesis, (2nd edition, pp 289-299). Food Science Text Series, New York: Springer-Verlag. http://dx.doi.org/10.1007/978$\underline{1-4939-7349-1 \_16}$

Bolinger, H., \& Kathariou, S. (2017). The Current State of Macrolide Resistance in Campylobacter spp.: Trends and Impacts of Resistance Mechanisms. Applied and Environmental Microbiology, 83 (12), 416-417. http://dx.doi.org/10.1128/aem.00416-17

Bolton, D. J. (2015). Campylobacter virulence and survival factors. Food Microbiology, 48, 99-108. http://dx.doi.org/10.1016/j.fm.2014.11.017

Bronowski, C., James, C. E., \& Winstanley, C. (2014). Role of environmental survival in transmission of Campylobacter jejuni. FEMS Microbiology Letters, 356 (1), 8-19. http://dx.doi.org/10.1111/1574-6968.12488

Burakoff, A., Brown, K., Knutsen, J., Hopewell, C., Rowe, S., Bennett, C., \& Cronquist, A. (2018). Outbreak of Fluoroquinolone-Resistant Campylobacter jejuni Infections Associated with Raw Milk Consumption from a Herdshare Dairy - Colorado, 2016. MMWR. Morbidity and Mortality Weekly Report, 67 (5), 146-148. http://dx.doi.org/10.15585/mmwr.mm6705a2

Butzler, J. P., Dekeyser, P., Detrain, M., \& Dehaen, F. (1973). Related vibrio in stools. The Journal of Pediatrics, 82 (3), 493-495. http://dx.doi.org/10.1016/s0022-3476(73)80131-3

Butzler, J.-P. (2004). Campylobacter, from obscurity to celebrity. Clinical Microbiology and Infection, 10 (10), 868-876. http://dx.doi.org/10.1111/j.14690691.2004.00983.x

Calciati, E., Lafuente, S., De Simó, M., Balfagon, P., Bartolomé, R., \& Caylà, J. (2012). A Campylobacter outbreak in a Barcelona school. Enfermedades Infecciosas y Microbiología Clínica, 30 (5), 243-245. http://dx.doi.org/10.1016/j.eimc.2011.10.004

CDC-Center for Disease Control and Prevention, (2014). Campylobacter. Available at http://www.cdc.gov/foodsafety/diseases/campylobacter/index.htm Accessed 23 May 2016

CDC - Center for Disease Control and Prevention, (2017). Foodborne Disease Active Surveillance Network (FoodNet): FoodNet 2015 Surveillance Report (Final Data), Atlanta, GA. Available online at: https://www.cdc.gov/foodnet/reports/annual-reports-2015.html

CDC - Centers for Disease Control and Prevention, (2018). Multistate outbreak of multidrug-resistant Campylobacter infections linked to contact with pet store puppies. Available at https://www.cdc.gov/campylobacter/outbreaks/puppies-9. 17/index.html

Cean, A., Stef, L., Simiz, E., Julean, C., Dumitrescu, G., Vasile, A., Pet, E., Drinceanu, D. \& Corcionivoschi, N. (2015). Effect of Human Isolated Probiotic Bacteria on Preventing Campylobacter jejuni Colonization of Poultry. Foodborne $\begin{array}{lllll}\text { Pathogens and } & \text { Disease, } & 12 & \text { (2), } & \text { 122-130. }\end{array}$ http://dx.doi.org/10.1089/fpd.2014.1849

Chaban, B., Ngeleka, M., \& Hill, J. E. (2010). Detection and quantification of 14 Campylobacter species in pet dogs reveals an increase in species richness in feces of diarrheic animals. BMC Microbiology, $10 \quad$ (1), 73 https://dx.doi.org/10.1186/1471-2180-10-73

Chon, J.-W., Kim, Y.-J., Kim, H.-S., Kim, D.-H., Kim, H., Song, K.-Y., \& Seo, K.-H. (2014). Supplementation of Bolton broth with triclosan improves detection of Campylobacter jejuni and Campylobacter coli in chicken carcass rinse. International Journal of Food Microbiology, 181, 37-39. https://dx.doi.org/10.1016/j.ijfoodmicro.2014.04.006

Cox, N. A., Richardson, L. J., Maurer, J. J., Berrang, M. E., Fedorka-Cray, P. J., Buhr, R. J., Byrd, J. A., Lee, M. D., Hofacre, C. L., O'Kane, P. M., Lammerding, A. M. Clark, A. G., Thayer, S. G. \& Doyle, M. P. (2012). Evidence for Horizontal and Vertical Transmission in Campylobacter Passage from Hen to Her Progeny. Journal of Food Protection, 75 (10), 1896-1902. https://dx.doi.org/10.4315/0362-028.jfp-11-322

Dasti, J. I., Tareen, A. M., Lugert, R., Zautner, A. E., \& Groß, U. (2010) Campylobacter jejuni: A brief overview on pathogenicity-associated factors and disease-mediating mechanisms. International Journal of Medical Microbiology, 300 (4), 205-211. https://dx.doi.org/10.1016/j.ijmm.2009.07.002

Debruyne, L., Gevers, D. \& Vandamme, P. (2008). Campylobacter. In Taxonomy of the family Campylobacteraceae (Third Edition, pp. 3-25). American Society of Microbiology. USA: Washington, DC. https://dx.doi.org/10.1128/9781555815554.ch1

Denis, M., Soumet, C., Rivoal, K., Ermel, G., Blivet, D., Salvat, G., \& Colin, P. (1999). Development of a m-PCR assay for simultaneous identification of Campylobacter jejuni and C. coli. Letters in Applied Microbiology, 29 (6), 406410. https://dx.doi.org/10.1046/j.1472-765x.1999.00658.x

Doyle, L. P. (1948). The etiology of swine dysentery. American Journal of Veterinary Research, 9 (30), 50-51.

EFSA-ECDC, (2009). The community summary report on trends and sources of zoonoses and zoonotic agents in the European Union in 2007. EFSA Journal, 7(1), 223r. https://dx.doi.org/10.2903/j.efsa.2009.223r

EFSA - European Food Safety Authority, (2017). The European Union summary report on trends and sources of zoonoses, zoonotic agents and foodborne outbreaks in 2016. EFSA Journal, 15 (12), e05077. https://doi.org/10.2903/j.efsa.2017.5077

Elango, A., Dhanalakshmi, B., Pugazhenthi, T. R., Jayalalitha, V., Rajarajan, G., Kumaresan, G., Naresh Kumar, C. \& Doraisamy, K. A. (2012). Seasonality of Campylobacter jejuni isolated from raw milk. Journal of Dairying Foods \& Home Sciences, 31 (1), 20-24.

Ellis-Iversen, J., Jorgensen, F., Bull, S., Powell, L., Cook, A. J., \& Humphrey, T. J. (2009). Risk factors for Campylobacter colonisation during rearing of broiler flocks in Great Britain. Preventive Veterinary Medicine, 89 (3-4), 178-184. https://dx.doi.org/10.1016/j.prevetmed.2009.02.004

Epps, S., Harvey, R., Hume, M., Phillips, T., Anderson, R., \& Nisbet, D. (2013) Foodborne Campylobacter: Infections, Metabolism, Pathogenesis and Reservoirs International Journal of Environmental Research and Public Health, 10 (12) 6292-6304. https://dx.doi.org/10.3390/ijerph10126292

European Centre for Disease Prevention, \& Control (2016). Annual epidemiological report 2016-Campylobacteriosis, Stockholm, ECDC, 2016. Avilable online at: https://www.ecdc.europa.eu/en/publicationsdata/campylobacteriosis-annual-epidemiological-report-2016-2014-data\#no-link Facciolà, A., Riso, R., Avventuroso, E., Visalli, G., Delia, S. A., \& Laganà, P. (2017). Campylobacter: from microbiology to prevention. Journal of preventive medicine and hygiene, 58 (2), E79.

Fitzgerald, C. (2015). Campylobacter. Clinics in Laboratory Medicine, 3 5(2), 289-298. https://dx.doi.org/10.1016/j.cll.2015.03.001

Fonseca, B. B., Beletti, M. E., Melo, R. T. de, Mendonça, E. P., Coelho, L. R., Nalevaiko, P. C., \& Rossi, D. A. (2014). Campylobacter jejuni in commercial eggs. Brazilian Journal of Microbiology, 45 (1), 76-79. https://dx.doi.org/10.1590/s1517-83822014000100011

Food and Drug Administration, (2013). Everything Added to Food in the United States (EAFUS). Doc. No. 3045-2, 4-Dihydroxybenzoic Acid. Available online at: http://www.accessdata.fda.gov/scripts/cdrh/cfdocs/cfCFR/CFRSearch.cfm? Food and Drug Administration, (2012). Code of Federal Regulations Title 21 Part 172 http://www.accessdata.fda.gov/scripts/cdrh/cfdocs/cfCFR/CFRSearch.cfm?.CFR Part1/4172

Friedrich, A., Marshall, J. C., Biggs, P. J., Midwinter, A. C., \& French, N. P. (2015). Seasonality of Campylobacter jejuni isolates associated with human campylobacteriosis in the Manawatu region, New Zealand. Epidemiology and Infection, 144 (4), 820-828. https://dx.doi.org/10.1017/s0950268815002009

FSA - Food Standard Agency, (2012). The European Union Summary Report on Trends and Sources of Zoonoses, Zoonotic agents and food-borne outbreaks in 2010. EFSA Journal, 10 (3):2597. https://dx.doi.org/10.2903/j.efsa.2012.2597

Galate, L. \& Bangde, S. (2015). Campylobacter - A Foodborne Pathogen. International Journal of Science and Research, 4 (3): 1250-1259.

Ganan, M., Silván, J. M., Carrascosa, A. V., \& Martínez-Rodríguez, A. J. (2012) Alternative strategies to use antibiotics or chemical products for controlling Campylobacter in the food chain. Food Control, 24 (1-2), 6-14. https://dx.doi.org/10.1016/j.foodcont.2011.09.027

García-Sánchez, L., Melero, B., Jaime, I., Hänninen, M.-L., Rossi, M., \& Rovira, J. (2017). Campylobacter jejuni survival in a poultry processing plant environment. Food Microbiology, 65, 185-192. https://dx.doi.org/10.1016/j.fm.2017.02.009

García-Sánchez, L., Melero, B. \& Rovira J. (2018). Campylobacter in the Food Chain. Advances in Food and Nutrition Research, 86, 215-252. https://dx.doi.org/10.1016/bs.afnr.2018.04.005

Ghosh, V., Mukherjee, A., \& Chandrasekaran, N. (2013). Ultrasonic emulsification of food-grade nanoemulsion formulation and evaluation of its bactericidal activity. Ultrasonics Sonochemistry, 20 (1), 338-344. https://dx.doi.org/10.1016/j.ultsonch.2012.08.010

Gölz, G., Rosner, B., Hofreuter, D., Josenhans, C., Kreienbrock, L., Löwenstein, A., Schielke , A., Stark, K., Suerbaum, S., Wieler, L. H. \& Alter, T. (2014) Relevance of Campylobacter to public health-The need for a One Health approach. International Journal of Medical Microbiology, 304 (7), 817-823. http://dx.doi.org/10.1016/j.ijmm.2014.08.015 
Gölz, G., Kittler, S., Malakauskas, M., \& Alter, T. (2018). Survival of Campylobacter in the Food Chain and the Environment. Current Clinical Microbiology Reports, 5 (2), 126-134. http://dx.doi.org/10.1007/s40588-0180092-Z

Georgiev, M., Beauvais, W., \& Guitian, J. (2016). Effect of enhanced biosecurity and selected on-farm factors on Campylobacter colonization of chicken broilers. Epidemiology and Infection, 145 (3), 553-567. http://dx.doi.org/10.1017/s095026881600251x

Goni, M. D., Muhammad, I. J., Goje, M., Abatcha, M. G., Bitrus, A. A. \& Abbas, M. A. (2017). Campylobacter in dogs and cats; its detection and public health significance: A review. Adv. Anim. Vet. Sci., 5 (6), 239-248.

Hazeleger, W. C., Bolder, N. M., Beumer, R. R., \& Jacobs-Reitsma, W. F. (2008). Darkling Beetles (Alphitobius diaperinus) and Their Larvae as Potential Vectors for the Transfer of Campylobacter jejuni and Salmonella enterica Serovar Paratyphi B Variant Java between Successive Broiler Flocks. Applied and Environmental Microbiology, 74 (22), 6887-6891. http://dx.doi.org/10.1128/aem.00451-08

Hermans, D., Van Deun, K., Martel, A., Van Immerseel, F., Messens, W., Heyndrickx, M., Haesebrouck, F. \& Pasmans, F. (2011). Colonization factors of Campylobacter jejuni in the chicken gut. Veterinary Research, 42 (1), 82 http://dx.doi.org/10.1186/1297-9716-42-82

Hu, L. \& Kopecko, D. (2018). Campylobacter species. In: food safety: rapid detection and effective prevention of foodborne hazards (first edition, pp. 55-92). USA: Silver Spring. http://dx.doi.org/110.1201/9781315109091

Hue, O., Le Bouquin, S., Laisney, M.-J., Allain, V., Lalande, F., Petetin, I. Rouxel, S., Quesne, S., Gloaguen, P. Y., Picherot, M., Santolini, J., Salvat, G., Bougeard, S. \& Chemaly, M. (2010). Prevalence of and risk factors for Campylobacter spp. contamination of broiler chicken carcasses at the slaughterhouse. Food Microbiology, $27 \quad$ (8), 992-999. http://dx.doi.org/10.1016/j.fm.2010.06.004

Humphrey, T., O'Brien, S., \& Madsen, M. (2007). Campylobacters as zoonotic pathogens: A food production perspective. International Journal of Food $\begin{array}{llll}\text { Microbiology, } & 117 & \text { (3), } & \text { 237-257. }\end{array}$ http://dx.doi.org/10.1016/j.ijfoodmicro.2007.01.006

Humphrey, S., Chaloner, G., Kemmett, K., Davidson, N., Williams, N., Kipar, A., Humphrey, T. \& Wigley, P. (2014). Campylobacter jejuni Is Not Merely a Commensal in Commercial Broiler Chickens and Affects Bird Welfare. MBio, 5 (4), e01364-14. http://dx.doi.org/10.1128/mbio.01364-14

Humphries, R. M., \& Linscott, A. J. (2015). Laboratory Diagnosis of Bacterial Gastroenteritis. Clinical Microbiology Reviews, 28 (1), 3-31. http://dx.doi.org/10.1128/cmr.00073-14

Ingresa-Capaccioni, S., González-Bodí, S., Jiménez-Trigos, E., Marco-Jiménez, F., Catalá, P., Vega, S., \& Marin, C. (2015). Comparison of different sampling types across the rearing period in broiler flocks for isolation of Campylobacter spp. Poultry Science, 94 (4), 766-771. http://dx.doi.org/10.3382/ps/pev023

Iovine, N. M. (2013). Resistance mechanisms in Campylobacter jejuni. Virulence, 4 (3), 230-240. http://dx.doi.org/10.4161/viru.23753

Jeon, B., Muraoka, W. T., \& Zhang, Q. (2010). Advances in Campylobacterbiology and implications for biotechnological applications Microbial Biotechnology, 3 (3), 242-258. http://dx.doi.org/10.1111/j.17517915.2009.00118.x

Jones, F. S., Orcutt, M., \& Little, R. B. (1931). Vibrios (Vibrio jejuni, n.sp.) Associated With Intestinal Disorders of Cows and Calves. The Journal of Experimental Medicine, 53 (6), 853-863. http://dx.doi.org/10.1084/jem.53.6.853 Kaakoush, N. O., Castaño-Rodríguez, N., Mitchell, H. M., \& Man, S. M. (2015) Global Epidemiology of Campylobacter Infection. Clinical Microbiology Reviews, 28 (3), 687-720. http://dx.doi.org/10.1128/cmr.00006-15

Keener, K. M., Bashor, M. P., Curtis, P. A., Sheldon, B. W., \& Kathariou, S. (2004). Comprehensive Review of Campylobacter and Poultry Processing. Comprehensive Reviews in Food Science and Food Safety, 3 (2), 105-116. http://dx.doi.org/10.1111/j.1541-4337.2004.tb00060.x

Kist, M. (1986). Wer entdeckte campylobacter jejuni/coli? Eine zusammenfassung bisher unberücksichtigter literaturquellen. Zentralblatt Für Bakteriologie, Mikrobiologie Und Hygiene. (Who discovered Campylobacter jejuni/coli? A historical review in german). Series A: Medical Microbiology, Infectious Diseases, Virology, Parasitology, 261(2), 177-186. http://dx.doi.org/10.1016/s0176-6724(86)80034-7

Koolman, L., Whyte, P., Burgess, C., \& Bolton, D. (2016). Virulence gene expression, adhesion and invasion of Campylobacter jejuni exposed to oxidative stress (H2O2). International Journal of Food Microbiology, 220, 33-38. http://dx.doi.org/10.1016/j.ijfoodmicro.2016.01.002

Koppenaal, H., Groenendijk, F., van den Berge, M., Verkade, E., Verduin, K. Zomer, A. L., Duim, B., Wagenaar, J. A., Tijsma, A. S. L., Spierenburg, M. A. H. $\&$ te Wierik, M. J. M. (2017). Outbreak of Campylobacter fetus infection after consumption of unpasteurized sheep's milk cheeses: how to trace the source? Nederlands tijdschrift voor geneeskunde, 161, D1704-D1704.

Kurinčič, M., Klančnik, A., \& Smole Možina, S. (2012). Effects of Efflux Pump Inhibitors on Erythromycin, Ciprofloxacin, and Tetracycline Resistance in Campylobacter spp. Isolates. Microbial Drug Resistance, 18 (5), 492-501. http://dx.doi.org/10.1089/mdr.2012.0017
Levin, R. E. (2007). Campylobacter jejuni: A Review of its Characteristics, Pathogenicity, Ecology, Distribution, Subspecies Characterization and Molecular Methods of Detection. Food Biotechnology, 21 (4), 271-347. http://dx.doi.org/10.1080/08905430701536565

Levy, A. J. (1946). A gastro-enteritis outbreak probably due to a bovine strain of vibrio. The Yale journal of biology and medicine, 18 (4), 243.

Linton, D., Owen, R. ., \& Stanley, J. (1996). Rapid identification by PCR of the genus Campylobacter and of five Campylobacter species enteropathogenic for man and animals. Research in Microbiology, 147 (9), 707-718. http://dx.doi.org/10.1016/s0923-2508(97)85118-2

Llarena, A-K. (2015). Population genetics and molecular epidemiology of Campylobacter jejuni. Ph.D. Thesis, Fac. Vet. Med. Helsinki Univ., Finland. http://urn.fi/URN:ISBN:978-951-51-1806-6

Llarena, A-K., Huneau, A., Hakkinen, M., \& Hänninen, M.-L. (2015) Predominant Campylobacter jejuni Sequence Types Persist in Finnish Chicken

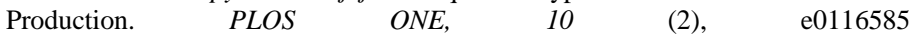
http://dx.doi.org/10.1371/journal.pone.0116585

Luangtongkum, T., Jeon, B., Han, J., Plummer, P., Logue, C. M., \& Zhang, Q. (2009). Antibiotic resistance in Campylobacter: emergence, transmission and persistence. Future Microbiology, 4 (2), 189-200. http://dx.doi.org/10.2217/17460913.4.2.189

Malakauskas, M., Malakauskas, A., Christensen, H., Olsen, J. E., \& Brogren, C. H. (2017). Repetitive Element Sequence-Based PCR Typing for Improved Discrimination of Campylobacter jejuni. Veterinarija ir Zootechnika, 75 (97), 43 53.

Man, S. M. (2011). The clinical importance of emerging Campylobacter species. Nature Reviews Gastroenterology \& Hepatology, 8 (12), 669-685. http://dx.doi.org/10.1038/nrgastro.2011.191

Mattson, T. E., Johny, A. K., Amalaradjou, M. A. R., More, K., Schreiber, D. T., Patel, J., \& Venkitanarayanan, K. (2011). Inactivation of Salmonella spp. on tomatoes by plant molecules. International Journal of Food Microbiology, 144 (3), 464-468. http://dx.doi.org/10.1016/j.ijfoodmicro.2010.10.035

Meade, K. G., Narciandi, F., Cahalane, S., Reiman, C., Allan, B., \& O’Farrelly, C. (2008). Comparative in vivo infection models yield insights on early host immune response to Campylobacter in chickens. Immunogenetics, 61 (2), 101110. http://dx.doi.org/10.1007/s00251-008-0346-7

Melero, B., Juntunen, P., Hänninen, M.-L., Jaime, I., \& Rovira, J. (2012). Tracing Campylobacter jejuni strains along the poultry meat production chain from farm to retail by pulsed-field gel electrophoresis, and the antimicrobial resistance of isolates. Food Microbiology, $32 \quad$ (1), 124-128. http://dx.doi.org/10.1016/j.fm.2012.04.020

Micciche, A., Rothrock, M. J., Yang, Y., \& Ricke, S. C. (2019). Essential Oils as an Intervention Strategy to Reduce Campylobacter in Poultry Production: A Review. Frontiers in Microbiology, 10, 1058 http://dx.doi.org/10.3389/fmicb.2019.01058

Miller, W. G., Parker, C. T., Heath, S., \& Lastovica, A. J. (2007). Identification of genomic differences between Campylobacter jejuni subsp. jejuni and C. jejuni subsp. doylei at the nap locus leads to the development of a $C$. jejuni subspeciation multiplex PCR method. BMC microbiology, 7, 11 . http://dx.doi.org/10.1186/1471-2180-7-11

Miller, W. G., \& Parker, C. T. (2011). Campylobacter and Arcobacter. In: Genomes of Foodborne and Waterborne Pathogens, (Fratamico, P., Liu, Y. \& Kathariou, S. (editors), pp 49-65). ASM Press, Washington, DC. http://dx.doi.org/10.1128/9781555816902.ch4

Ministry for Primary Industries, (2015). Annual report of information on potentially foodborne diseases in New Zealand 2014. Available online a https://www.mpi.govt.nz/food-safety/food-safety-and-suitability-research/humanhealth-surveillancelfoodborne-disease-annual-reports/

Mungai, E. A., Behravesh, C. B., \& Gould, L. H. (2015). Increased Outbreaks Associated with Nonpasteurized Milk, United States, 2007-2012. Emerging Infectious Diseases, 21 (1), 119-122. http://dx.doi.org/10.3201/eid2101.140447 Nachamkin, I., Szymanski, C. \& Blaser, M. (2008). Campylobacter (Third Edition). Washington, DC: ASM Press, ISBN: 978-1-55581-437-3. http://dx.doi.org/10.1128/9781555815554

Neal-McKinney, J. M., \& Konkel, M. E. (2012). The Campylobacter jejuni CiaC virulence protein is secreted from the flagellum and delivered to the cytosol of host cells. Frontiers in Cellular and Infection Microbiology, 2, 1-15, article 31 http://dx.doi.org/10.3389/fcimb.2012.00031

Newell, D. G., Elvers, K. T., Dopfer, D., Hansson, I., Jones, P., James, S. Gittins, J., Stern, N. J., Davies, R., Connerton, I., Pearson, D., Salvat, G., \& Allen, V. M. (2011). Biosecurity-Based Interventions and Strategies To Reduce Campylobacter spp. on Poultry Farms. Applied and Environmental Microbiology, 77 (24), 8605-8614. http://dx.doi.org/10.1128/aem.01090-10

NNDSS-Australian National Notifiable Diseases Surveillance System, (2016) Australia's notifiable disease status, 2014. In: Annual report of the national Notifiable diseases surveillance system: part 1. Available at http://www.health.gov.au/internet/main/publishing.nsf/Content/cda-cdi4001e.htm On, S. L. W. (2001). Taxonomy of Campylobacter, Arcobacter, Helicobacter and related bacteria: current status, future prospects and immediate concerns. Journal 
of Applied Microbiology, 90 (S6), 1S-15S. http://dx.doi.org/10.1046/j.13652672.2001.01349.x

PHE-Public Health England, (2017). A microbiological survey of Campylobacter contamination in fresh whole UK-produced chilled chickens at retail sale. FSA Project, FS102121 year-2- report2017. Available at: https://www.food.gov.uk/research/foodborne-diseases/a-microbiological-surveyof-campylobacter-contamination-in-fresh-whole-uk-produced-chilled-chickens-

at-retail-sale-y234

Pintar, K. D. M., Christidis, T., Thomas, M. K., Anderson, M., Nesbitt, A., Keithlin, J., ... Pollari, F. (2015). A Systematic Review and Meta-Analysis of the Campylobacter spp. Prevalence and Concentration in Household Pets and Petting Zoo Animals for Use in Exposure Assessments. PLOS ONE, 10 (12), e0144976. http://dx.doi.org/10.1371/journal.pone.0144976

Pitkänen, T. (2013). Review of Campylobacter spp. in drinking and environmental waters. Journal of Microbiological Methods, 95 (1), 39-47. http://dx.doi.org/10.1016/j.mimet.2013.06.008

Platts-Mills, J. A., \& Kosek, M. (2014). Update on the burden of Campylobacter in developing countries. Current Opinion in Infectious Diseases, 27 (5), 444-450. http://dx.doi.org/10.1097/qc0.0000000000000091

Public Health Agency of Canada, (2017). Notifiable disease chart 'Campylobacter'. Available at: http://diseases.canada.ca/notifiable/diseases-list Revez, J., \& Hänninen, M.-L. (2012). Lipooligosaccharide locus classes are associated with certain Campylobacter jejuni multilocus sequence types European Journal of Clinical Microbiology \& Infectious Diseases, 31 (9), 22032209. http://dx.doi.org/10.1007/s10096-012-1556-3

Ridley, A., Morris, V., Gittins, J., Cawthraw, S., Harris, J., Edge, S., \& Allen, V. (2011). Potential sources of Campylobacter infection on chicken farms: contamination and control of broiler-harvesting equipment, vehicles and personnel. Journal of Applied Microbiology, 111 (1), 233-244. http://dx.doi.org/10.1111/j.1365-2672.2011.05038.x

Rowe, M. T. \& Madden, R. H. (2014). Campylobacter introduction. In Encyclopedia of Food Microbiology, (Batt, C. A. \& Tortorello, M. L. (Editors), second edition, pp. 351-356), Academic Press, Elsevier. http://dx.doi.org/10.1016/b978-0-12-384730-0.00052-5

Sahin, O., Kassem, I. I., Shen, Z., Lin, J., Rajashekara, G., \& Zhang, Q. (2015). Campylobacter in Poultry: Ecology and Potential Interventions. Avian Diseases, 59 (2), 185-200. http://dx.doi.org/10.1637/11072-032315-review

Same, R. G., \& Tamma, P. D. (2018). Campylobacter Infections in Children Pediatrics in Review, 39 (11), 533-541. http://dx.doi.org/10.1542/pir.2017-0285 Samuelson, D. R., Eucker, T. P., Bell, J. A., Dybas, L., Mansfield, L. S., \& Konkel, M. E. (2013). The Campylobacter jejuni $\mathrm{CiaD}$ effector protein activates MAP kinase signaling pathways and is required for the development of disease. Cell Communication and Signaling, 11 (1), 79. http://dx.doi.org/10.1186/1478$\underline{811 \mathrm{x}-11-79}$

Sebald, M. \& Veron, M. (1963). Base DNA content and classification of vibrios. Annales de I'Institut Pasteur, 105, 897-910.

Shen, Z., Wang, Y., Zhang, Q., \& Shen, J. (2018). Antimicrobial Resistance in Campylobacter spp. Microbiology Spectrum, $6 \quad$ (2), 1-13. http://dx.doi.org/10.1128/microbiolspec.arba-0013-2017

Sibanda, N., McKenna, A., Richmond, A., Ricke, S. C., Callaway, T., Stratakos, A. C., Gundogdu, O. \& Corcionivoschi, N. (2018). A Review of the Effect of Management Practices on Campylobacter Prevalence in Poultry Farms. Frontiers in Microbiology, 9, 2002. http://dx.doi.org/10.3389/fmicb.2018.02002

Silva, J., Leite, D., Fernandes, M., Mena, C., Gibbs, P. A., \& Teixeira, P. (2011) Campylobacter spp. as a Foodborne Pathogen: A Review. Frontiers in Microbiology, 2, 200. http://dx.doi.org/10.3389/fmicb.2011.00200

Silva, W. C., Targino, B. N., Gonçalves, A. G., Silva, M. R., \& Hungaro, H. M. (2018a). Campylobacter: An Important Food Safety Issue. In: Food Safety and Preservation, (Grumezescu, A. M. \& Holban, A. M. (editors), pp 391-430) http://dx.doi.org/10.1016/b978-0-12-814956-0.00013-5

Silva, W. C., Targino, B. N., Mendonça, R. S., Sant'Ana, A. S., \& Hungaro, H. M. (2018b). Campylobacter: An overview of cases, occurrence in food, contamination sources, and antimicrobial resistance in Brazil. Food Reviews International, 34 (4), 364-389. http://dx.doi.org/10.1080/87559129.2017.1298125

Skarp, C. P. A., Hänninen, M.-L., \& Rautelin, H. I. K. (2016). Campylobacteriosis: the role of poultry meat. Clinical Microbiology and Infection, 22 (2), 103-109. http://dx.doi.org/10.1016/j.cmi.2015.11.019

Skirrow, M. B. (1977). Campylobacter enteritis: a "new" disease. British Medical Journal, 2 (6078), 9-11. http://dx.doi.org/110.1136/bmj.2.6078.9

Smith, T., \& Taylor, M. S. (1919). Some Morphological and Biological Characters of The Spirilla (Vibrio fetus, N. Sp.) Associated With Disease of The Fetal Membranes in Cattle. The Journal of Experimental Medicine, 30 (4), 299311. http://dx.doi.org/10.1084/jem.30.4.299

Thibodeau, A., Fravalo, P., Yergeau, E., Arsenault, J., Lahaye, L., \& Letellier, A. (2015). Chicken Caecal Microbiome Modifications Induced by Campylobacter jejuni Colonization and by a Non-Antibiotic Feed Additive. PLOS ONE, 10 (7), e0131978. http://dx.doi.org/10.1371/journal.pone.0131978
Tran, T. T. (1998). A blood-free enrichment medium for growing Campylobacter spp. under aerobic conditions. Letters in Applied Microbiology, 26 (2), 145-148. http://dx.doi.org/10.1046/j.1472-765x.1998.00295.x

Ugarte-Ruiz, M., Domínguez, L., Corcionivoschi, N., Wren, B. W., Dorrell, N., \& Gundogdu, O. (2018). Exploring the oxidative, antimicrobial and genomic properties of Campylobacter jejuni strains isolated from poultry. Research in Veterinary Science, 119, 170-175. http://dx.doi.org/10.1016/j.rvsc.2018.06.016

Upadhyay, A., Upadhyaya, I., Kollanoor-Johny, A., Ananda Baskaran, S., Mooyottu, S., Karumathil, D., \& Venkitanarayanan, K. (2013a). Inactivation of Listeria monocytogenes on frankfurters by plant-derived antimicrobials alone or in combination with hydrogen peroxide. International Journal of Food Microbiology, $\quad 163 \quad(2-3)$,

http://dx.doi.org/10.1016/j.ijfoodmicro.2013.01.023

Upadhyaya, I., Upadhyay, A., Kollanoor-Johny, A., Baskaran, S. A., Mooyottu, S., Darre, M. J., \& Venkitanarayanan, K. (2013b). Rapid inactivation of Salmonella enteritidis on shell eggs by plant-derived antimicrobials. Poultry Science, 92 (12), 3228-3235. http://dx.doi.org/10.3382/ps.2013-03126

Upadhyay, A., Upadhyaya, I., Karumathil, D. P., Yin, H., Nair, M. S., Bhattaram, V. \&Venkitanarayanan, K. (2015). Control of Listeria monocytogenes on skinless frankfurters by coating with phytochemicals. LWT - Food Science and Technology, 63 (1), 37-42. http://dx.doi.org/10.1016/j.lwt.2015.03.100

Upadhyay, A., Arsi, K., Wagle, B. R., Upadhyaya, I., Shrestha, S., Donoghue, A. M., \& Donoghue, D. J. (2017). Trans-Cinnamaldehyde, Carvacrol, and Eugenol Reduce Campylobacter jejuni Colonization Factors and Expression of Virulence Genes in Vitro. Frontiers in Microbiology, 8, 713. http://dx.doi.org/10.3389/fmicb.2017.00713

Upadhyay, A., Arsi, K., Upadhyaya, I., Donoghue, A. M., \& Donoghue, D. J. (2019). Natural and Environmentally Friendly Strategies for Controlling Campylobacter jejuni Colonization in Poultry, Survival in Poultry Products and Infection in Humans. In: Food Safety in Poultry Meat Production, (Venkitanarayanan, K., Thakur, S. \& Ricke, S. (editors) Food Microbiology and Food Safety, pp 67-93). Springer, Cham. http://dx.doi.org/10.1007/978-3-03005011-5 4

Van Dyke, M. I., Morton, V. K., McLellan, N. L., \& Huck, P. M. (2010). The occurrence of Campylobacter in river water and waterfowl within a watershed in southern Ontario, Canada. Journal of Applied Microbiology, 109 (3), 1053-1066. http://dx.doi.org/10.1111/j.1365-2672.2010.04730.x

Van Gerwe, T., Miflin, J. K., Templeton, J. M., Bouma, A., Wagenaar, J. A., Jacobs-Reitsma, W. F., Stegeman, A. \& Klinkenberg, D. (2008). Quantifying Transmission of Campylobacter jejuni in Commercial Broiler Flocks. Applied and Environmental Microbiology, 75 (3), 625-628 http://dx.doi.org/10.1128/aem.01912-08

Verhoeff-Bakkenes, L., Jansen, H. A. P. M., in 't Veld, P. H., Beumer, R. R, Zwietering, M. H., \& van Leusden, F. M. (2011). Consumption of raw vegetables and fruits: A risk factor for Campylobacter infections. International Journal of $\begin{array}{llll}\text { Food } \quad \text { Microbiology, } & 144 & \text { (3), } & 406-412\end{array}$ http://dx.doi.org/10.1016/j.ijfoodmicro.2010.10.027

Veron, M., \& Chatelain, R. (1973). Taxonomic Study of the Genus Campylobacter Sebald and Veron and Designation of the Neotype Strain for the Type Species, Campylobacter fetus (Smith and Taylor) Sebald and Veron. International Journal of Systematic Bacteriology, 23 (2), 122-134. http://dx.doi.org/10.1099/00207713-23-2-122

Vondrakova, L., Pazlarova, J., \& Demnerova, K. (2014). Detection, identification and quantification of Campylobacter jejuni, coli and lari in food matrices all at once using multiplex qPCR. Gut Pathogens, 6 (1), 12 https://dx.doi.org/10.1186/1757-4749-6-12

Wagle, B. R., Arsi, K., Upadhyay, A., Shrestha, S., Venkitanarayanan, K., Donoghue, A. M., \& Donoghue, D. J. (2017a). ß-Resorcylic Acid, a Phytophenolic Compound, Reduces Campylobacter jejuni in Postharvest Poultry. Journal of Food Protection, 80 (8), 1243-1251. https://dx.doi.org/10.4315/0362028x.jpp-16-475

Wagle, B. R., Upadhyay, A., Arsi, K., Shrestha, S., Venkitanarayanan, K., Donoghue, A. M., \& Donoghue, D. J. (2017b). Application of $\beta$-Resorcylic Acid as Potential Antimicrobial Feed Additive to Reduce Campylobacter Colonization in Broiler Chickens. Frontiers in Microbiology, 8, 599 https://dx.doi.org/10.3389/fmicb.2017.00599

Wagle, B. R., Arsi, K., Shrestha, S., Upadhyay, A., Upadhyaya, I., Bhargava, K., Donoghue, A. \& Donoghue, D. J. (2019). Eugenol as an antimicrobial wash treatment reduces Campylobacter jejuni in postharvest poultry. Journal of Food Safety, 39 (6). e12704. 1-11. https://dx.doi.org/10.1111/jfs.12704

Whiley, H., van den Akker, B., Giglio, S., \& Bentham, R. (2013). The Role of Environmental Reservoirs in Human Campylobacteriosis. International Journal of Environmental Research and Public Health, 10 (11), 5886-5907. https://dx.doi.org/10.3390/ijerph10115886

Whitehouse, C. A., Zhao, S. \& Tate, H. (2018). Antimicrobial Resistance in Campylobacter Species: Mechanisms and Genomic Epidemiology. Advances in Applied Microbiology,103,

https://dx.doi.org/10.1016/bs.aambs.2018.01.001

WHO - World Health Organization, (2015). WHO estimates of the global burden of foodborne diseases: foodborne disease burden epidemiology reference group 
2007-2015.

WHO - World Health Organization, (2016). Campylobacter. Available at http://www.who.int/mediacentre/factsheets/fs255/en/

Wieczorek, K., \& Osek, J. (2013). Antimicrobial Resistance Mechanisms among Campylobacter. BioMed Research International, 2013, 1-12. https://dx.doi.org/10.1155/2013/340605

Williams, M. S., Golden, N. J., Ebel, E. D., Crarey, E. T., \& Tate, H. P. (2015) Temporal patterns of Campylobacter contamination on chicken and their relationship to campylobacteriosis cases in the United States. International

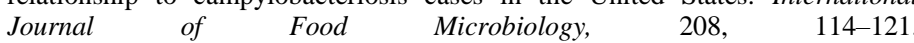
https://dx.doi.org/10.1016/j.ijfoodmicro.2015.05.018

Yamazaki-Matsune, W., Taguchi, M., Seto, K., Kawahara, R., Kawatsu, K., Kumeda, Y. \& Tsukamoto, T. (2007). Development of a multiplex PCR assay for identification of Campylobacter coli, Campylobacter fetus, Campylobacter hyointestinalis subsp. hyointestinalis, Campylobacter jejuni, Campylobacter lari and Campylobacter upsaliensis. Journal of Medical Microbiology, 56 (11), 1467-1473. https://dx.doi.org/10.1099/jmm.0.47363-0

Yao, H., Liu, D., Wang, Y., Zhang, Q., \& Shen, Z. (2017). High Prevalence and Predominance of the aph(2")-If Gene Conferring Aminoglycoside Resistance in Campylobacter. Antimicrobial Agents and Chemotherapy, 61 (5), 1-9. https://dx.doi.org/10.1128/aac.00112-17

Zhang, T., Luo, Q., Chen, Y., Li, T., Wen, G., Zhang, R., Luo, L., Lu, Q., Ai, D., Wang, H. \& Shao, H. (2016). Molecular epidemiology, virulence determinants and antimicrobial resistance of Campylobacter spreading in retail chicken meat in Central China. Gut Pathogens, 8 (1), 48. https://dx.doi.org/10.1186/s13099-016$\underline{0132-2}$

Zilbauer, M., Dorrell, N., Wren, B. W., \& Bajaj-Elliott, M. (2008) Campylobacter jejuni-mediated disease pathogenesis: an update. Transactions of the Royal Society of Tropical Medicine and Hygiene, 102 (2), 123-129. https://dx.doi.org/10.1016/j.trstmh.2007.09.019 